\title{
DIRECTIONS IN LOW-LEVEL RADIOACTIVE WASTE MANAGEMENT A Brief History of Commercial Low-Level Radioactive Waste Disposal
}

\section{DISCLAIMER}

This report was prepared as an account of work sponsored by an agency of the U', ited States Government. Neither the United States Government nor any agency thereof, nor any of their emplo: :es, makes any warranty, express or implied, or assumes any legal liability or responsibility for the accuracy, completeness, or usefulness of any information, apparatus, product, or process disclosed, or represents that its use would not infringe privately cwned rights. Reference herein to any specific commercial product, process, or service by trade name, trademark, manufacturer, or otherwise does not necessarily constitute or imply its endorsement, recommendation, or favoring by the United States Government or any agency thereof. The views and opinions of nuthors expressed herein do not necessarily state or reflect those of the United States Government or any agency thereof.

\author{
Prepared at the \\ Idaho National Enginee, ing Laboratory \\ by the \\ National Low-Level "aste Management Program \\ For the \\ U.S. Department of Energy \\ Under DOE Contract No. DE-AC07-76ID01570
}




\section{ABSTRACT}

This report presents a history of commercial low-level radioactive waste management in the United States, with emphasis on the history of six commercially operated low-level radioactive waste disposal facilities. The report includes a brief description of important steps that have been taken during the $1980 \mathrm{~s}$ to ensure the safe disposal of low-level waste in the $1990 \mathrm{~s}$ and beyond. These steps include the issuance of Title 10 Code of Federal Regulations Part 61, Licensing Requirements for the Land Disposal of Radioactive Waste, the Low-Level Radioactive Waste Policy Act of 1980, the Low-Level Radioactive Waste Policy Amendments Act of 1985, and steps taken by States and regional compacts to establish additional disposal sites. 


\section{FOREWORD}

This document updates the information presented in two Department of Energy reports Directions in Low-Level Radioactive Waste Management, Low-Level Radioactive Waste Disposal: Commercial Facilities No Loriger Operating, dated October 1982, and Directions in Low-Level Radioactive Waste Management, Low-Level Radioactive Waste Disposal: Currently operating Commercial

Facilities, dated September 1983. 


\section{CONTENTS}

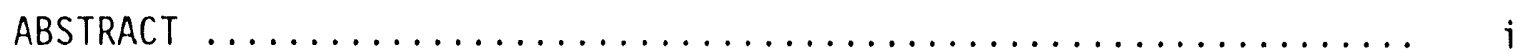

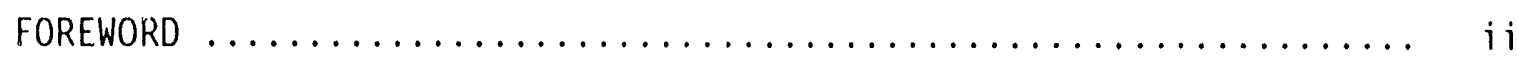

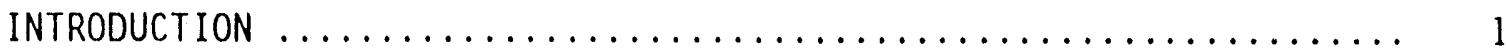

PART ONE: LOW-LEVEL RADIOACTIVE WASTE DISPOSAL .............. 4

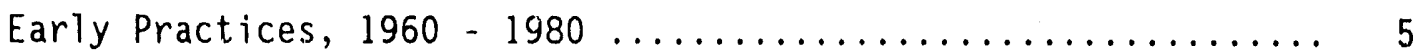

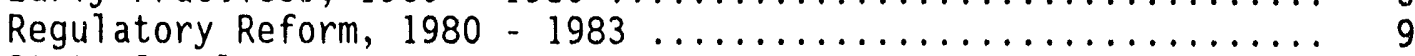

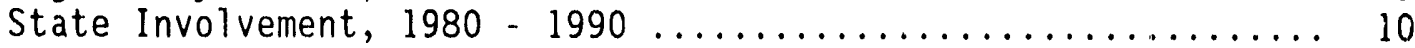

PART TWO: HISTORIES OF SIX LOW-LEVEL RADIOACTIVE WASTE

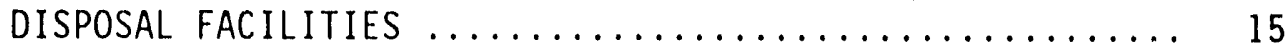

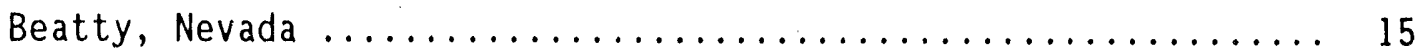

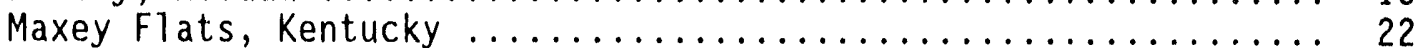

West Valley, New York ............................. 30

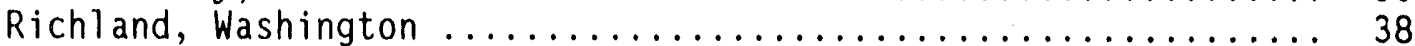

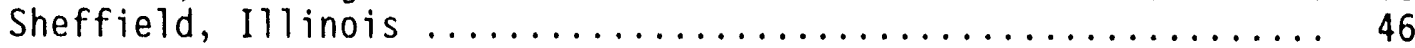

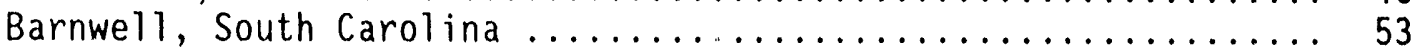

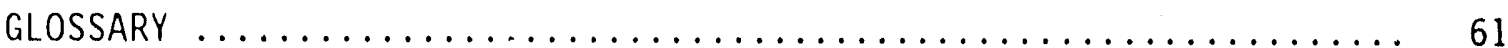

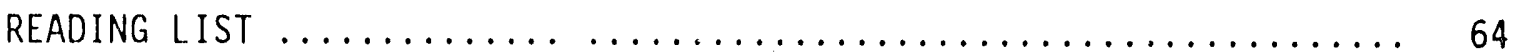

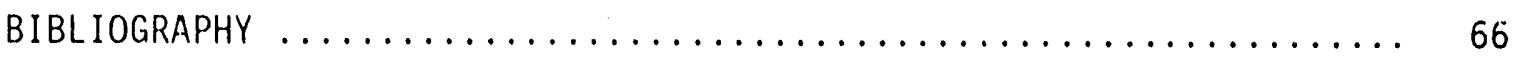

APPENDIX A--RADIATION BASICS ...................... A-1

APPENDIX B--RADIONUCLIDE MIGRATION AND PERFORMANCE ASSESSMENT ...... B-I APPENDIX $C$--DISPOSAL TECHNOLOGIES $\ldots \ldots \ldots \ldots \ldots \ldots \ldots \ldots \ldots \ldots, \ldots \ldots$

FIGURES

1. Commercial low-level radioactive waste disposal facilities .... 2

2. Beatty, Nevada, disposal facility site geology ............ 16

3. Beatty, Nevada, disposal facility map .................. 18

4. Maxey Flats, Kentucky, disposal facility site geology ........ 24

5. Maxey Flats, Kentucky, disposal facility map ............. 25 
6. West Valley, New York, disposal facility site geology ...... 32

7. West Valley, New York, disposal facility map ............ 33

8. Richland, Washington, disposal facility site geology ....... 40

9. Richland, Washington, disposal facility map ............. 41

10. Sheffield, Illinois, disposal facility site geology ........ 48

11. Sheffield, Illinois, disposal facility map ............ 49

12. Barnwe11, South Carolina, disposal facility site geology ..... 55

13. Barnwell, South Carolina, disposal facility map .......... 56

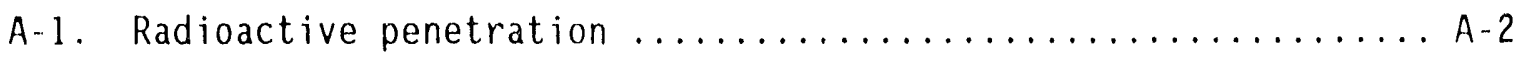

A-2. Natural decay curve of radionuclides $\ldots \ldots \ldots \ldots \ldots \ldots \ldots \ldots$

B-1. Potential radionuclide migration and exposure pathways ...... B-2

C-1. Shallow-land disposal concept $\ldots \ldots \ldots \ldots \ldots \ldots \ldots \ldots \ldots \ldots \ldots \ldots$

C-2. Belowground vault disposal concept $\ldots \ldots \ldots \ldots \ldots \ldots \ldots \ldots \ldots$

C-3. Aboveground vault disposal concept $\ldots \ldots \ldots \ldots \ldots \ldots \ldots \ldots \ldots$

TABLES

1. Volume and activity of waste disposed of at six low-level waste disposal facilities ......................... 6

A-1. Half-lives for representative radionuclides in commercially generated low-level radioactive waste $\ldots . \ldots \ldots \ldots \ldots \ldots \ldots . . \ldots$ 


\section{DIRECTIONS IN LOW-LEVEL RADIOACTIVE WASTE MANAGEMENT \\ A Brief History of Commercial \\ Low-Level Radioactive Waste Disposal}

\section{INTRODUCTION}

As part of the effort by the U.S. Department of Energy's National Low-l.evel Waste Management Program to develop and make available useful information concerning low-level waste management, this report provides a brief history of the development of low-level radioactive waste disposal, including early practices and experiences, the development of comprehensive Federal and State regulations, and the enactment of legislation which assigns responsibilities and creates the framework under which low-level radioactive waste management and disposal operations are now carried out. It also contains a summary of the operational histories of commercially operated low-level radioactive waste disposal facilities in the United States.

This examination of the history of low-level radioactive waste disposal practices and of the development of the regulations governing these practices is intended to be instructive and to provide a basic understanding of commercial low-level radioactive waste management in the United States today. To that end, the report has been written for readers who do not have extensive backgrounds in low-level waste management but who are interested in its history and in current practices.

Six commercially operated shallow-land disposal facilities have been licensed and operated in the United States (Figure 1). Five of these sites were licensed by the Host States under agreements with the U.S. Nuclear Regulatory Commission (NRC). The sixth, located in Illinois (which was not an Agreement State), was licensed by the NRC. Three of the sites have been closed for over 10 years. The sites in West Valley, New York, and Maxey Flats, Kentucky, were closed in 1975 and 1977 respectively, as a result of water management problems. In 1978, the site in Sheffield, Illinois, was closed after the operator experienced lengthy delays with its NRC license renewal. The other three disposal facilities (located in Beatty, Nevada; 


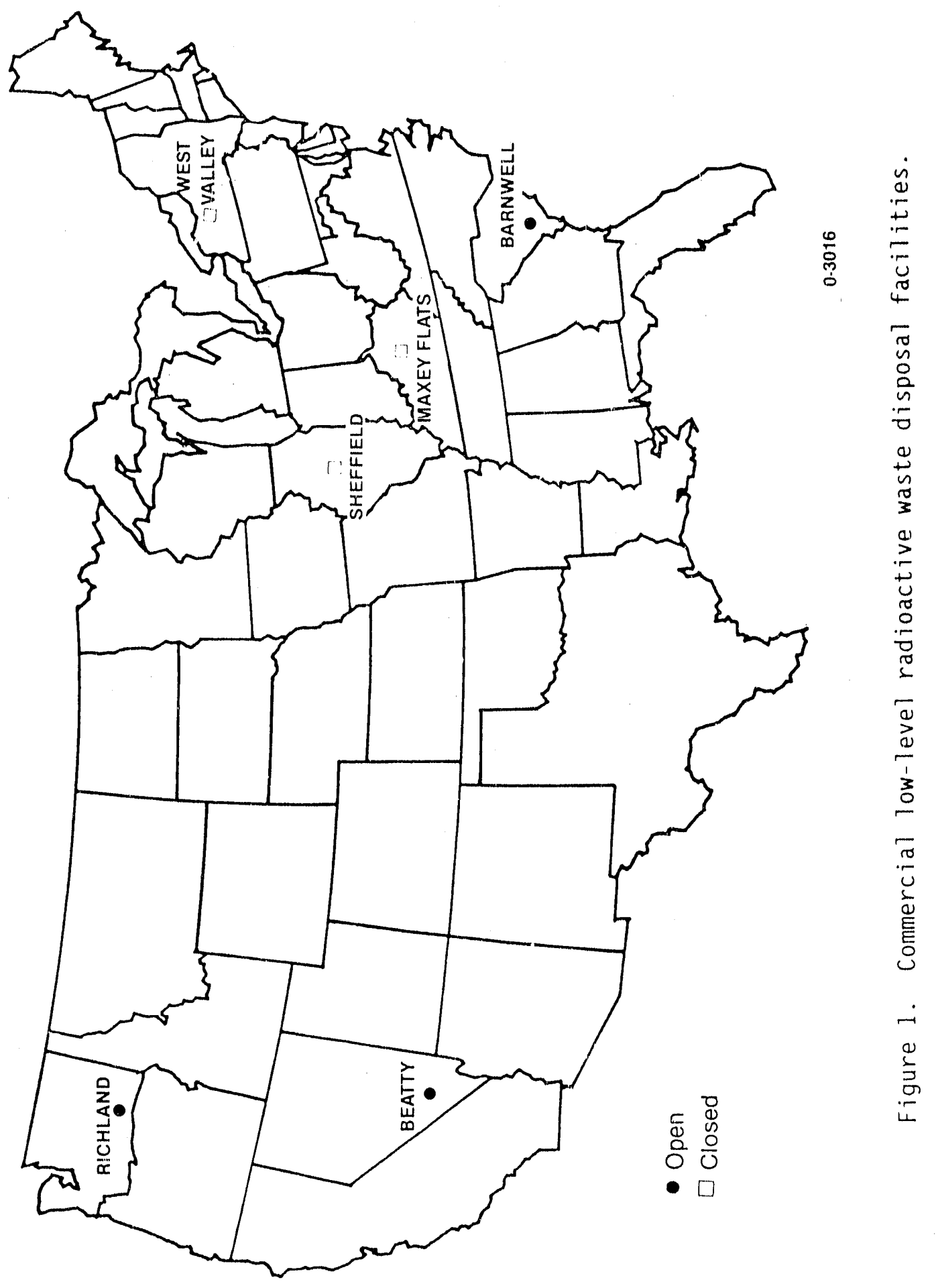


Richland, Washington; and Barnwell, South Carolina), have operated successfully and continue to receive and dispose of low-level waste. The experience resulting from the operation of these six disposal facilities was reflected in the issuance of Title 10 Code of Federal Regulations, Part 61 Licensing Requirements for the Land Disposal of Radioactive Waste (1983), the Low-Level Radioactive Waste Policy Act of 1980, and the Low-Level Radioactive Waste Policy Amendments Act of 1985.

The report is divided into two parts. Part 1 discusses the history of low-level waste management, dividing the information into historical periods and discussing directions for the next decade. Part 2 includes individual histories of the six disposal sites. A glossary of terms is included. The appendices provide further information on radioactive decay, radionuclide migration, performance assessment, and disposal technologies. In addition, a reading list has been furnished. The material used in preparing this document was obtained from existing records and reports, State and Federal officials, and site operators. A bibliography is provided at the end of the document. 
PART ONE

LOW-LEVEL RADIOACTIVE WASTE DISPOSAL

With the growth of commercial applications of nuclear technologies, the Atomic Energy Commission (AEC) announced in 1960 that regional land disposal sites for commercially generated low-level radioactive waste should be established and that the sites should be operated by the private sector subject to government 1 icensing authority. With this announcement, the AEC (now the Department of Energy and the Nuclear Regulatory Commission) indicated that the disposal sites it had operated would remain available for use by waste generators outside the AEC only until adequate d: sposal capacity was established in the private sector. At the same time, the AEC began a phase-out of sea disposal operations.

Six commercially operated low-level radioactive waste disposal facilities have been 1 icensed and operated since the $A E C^{\prime}$ 's announcement in 1960. These facilities are located in Beatty, Nevada; Maxey Flats, Kentucky; West Valley, New York; Richland, Washington; Sheffield, Illinois; and Barnwe11, South Carolina. The Beatty facility, which opened in 1962, was the first to begin commercial disposal operations; the Barnwell facility, which opened in 1971, was the last. Three of the facilities (Maxey Flats, West Valley, and Sheffield) have since closed. The other three facilities (Beatty, Richland, and Barnwel1) are still operating successfully and dispose of all the commercial low-leve i radioactive waste currently generated in the United States.

The six commercially operated low-level radioactive waste disposal facilities have received waste from educational, research, medical, pharmaceutical, and industrial sources, and from nuclear power plants. Most. of the low-level waste received from sources other than nuclear power plants consists of radiologically contaminated paper, packaging material, rags, protective clothing, laboratory glassware, gloves, wood, filters, and failed and obsolete components. Power-plant waste consists of contaminated dry solids, expended filter media, and absorbed or solidified liquids. The 
estimated quantities and radioactivity of the waste disposed of in each site are summarized in Table 1.

$$
\text { Early Practices, } 1961 \quad 1980
$$

The commercially operated low-level radioactive disposal sites adopted shallow-land disposal technologies that had been established and utilized by the AEC. These procedures were commonly used at national laboratories involved in atomic energy research and development and in defense programs which generated radioactive waste requiring disposal. Shallow-land disposal could be used near the point where the waste was generated, thereby reducing transportation costs. In addition, shallow-land disposal proved to be a cost-effective technique because it employed practices commonly used in sanitary landfill operations and did not require unusual equipment or construction techniques.

The overall performance of the six low-level waste disposal facilities has varied from unsatisfactory to very good. Problems were encountered at the three sites that have been closed. Most significant were problems with site instability coupled with difficulties in surface and groundwater maragement. These problems led to radionuclide migration (see Appendix B) and have required remedial measures to maintain the protection of public health and safety and the environment. Such measures have required the commitment of resources far beyond those originally anticipated to care for and maintain the sites. The instability experienced at the sites has also made prediction of long-term performance of these sites difficult. Experience at these sites indicates that a combination of unstable waste forms, specific site characteristics, and certain design and operational practices led to problems with water management and site instability. There were also problems with respect to financial assurance and institutional control of the sites. 
Table 1. Volume and activity of waste disposed of at six low-level waste disposal facilities.

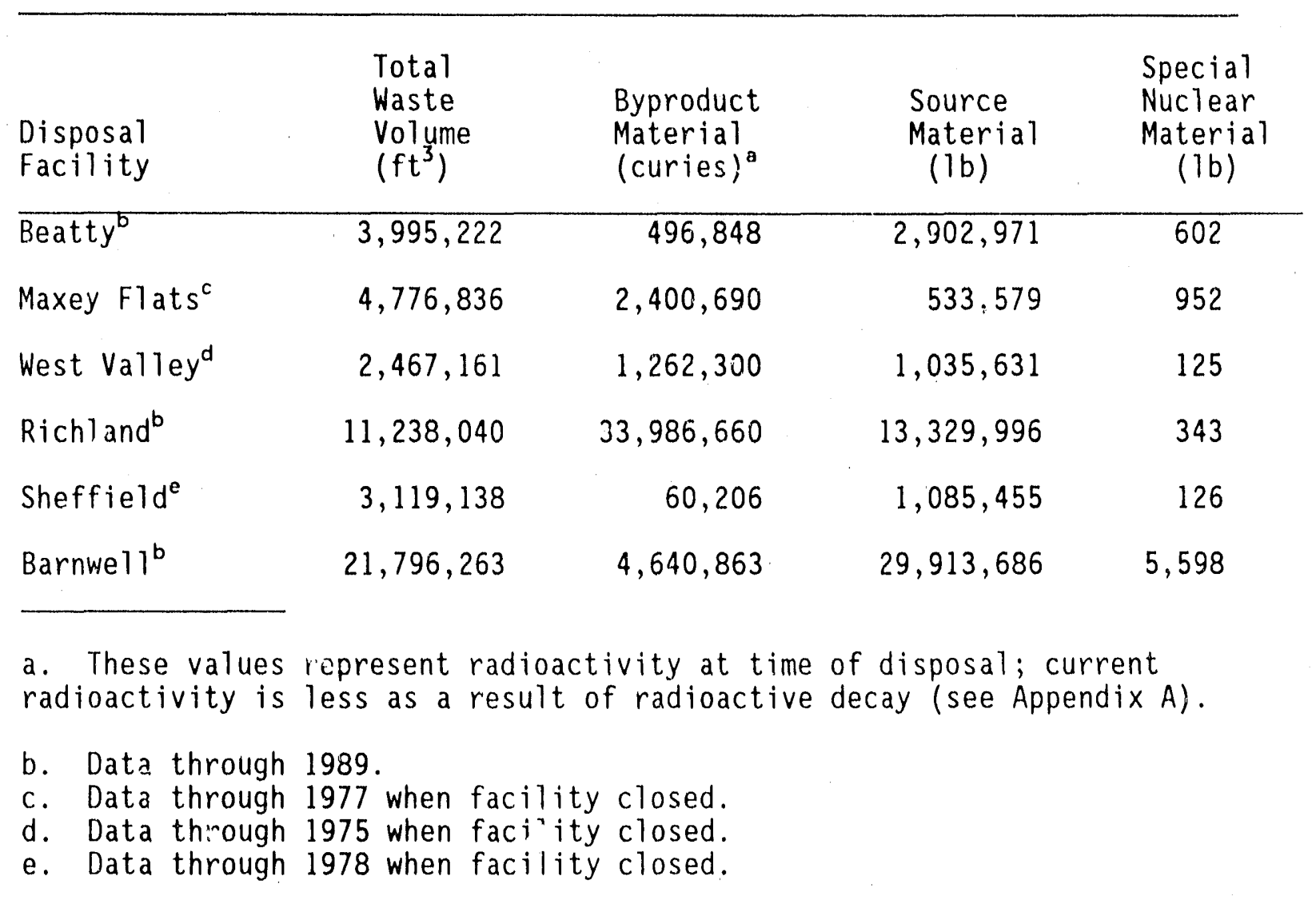


Inadequate waste form was ore of the most significant factors leading to the difficulties experienced at the closed sites. Waste forms sent to the sites reflected general practices of the times. Licensees were encouraged to send all suspect wastes for disposal, and waste minimization and volume reduction were not required. Most of the waste that was disposed of at the sities is believed to have been either composed of very easily degradable material or packaged so that large void spaces existed within the waste or between the waste and the packaging. Some of the waste packages (such as cardboard and fiberboard boxes) were often easily degradable. Also, the wastes often contained chemical agents that enhanced waste degradation and leaching of radionuclides. Frequently, these easily degraded wastes contained little or no radioactivity.

As the waste materiai degraded and compressed, a process which was accelerated by contact with water, additional voids ivere produced. These voids led to settlement of the disposal trench contents, followed by subsidence or slumping of the disposal trench covers, which in turn increased the percolation of water into the disposal trenches and accelerated tho degradation cycle. In many cases, the soil in which the trench was dug was less permeable to water than the soil which was used to cover the trench. This difference in permeability allowed the trenches to fill with water, a phenomenon known as the "bathtub effect."

Early operating practices also contributed to rapid waste degradation, subsequent slumping of the trench covers, and influx of precipitation. Waste was placed within the disposal trenches with little or no attempt to segregate wastes according to characteristics (such as chemical content or the relative stability of the waste packages). In general, little compaction was applied to the disposed waste, backfill, and trench covers other than that provided by driving over the disposal trenches with heavy trucks. Thus, considerable void spaces probably existed within the trenches, promoting rapid settling. Another factor was that water was frequently allowed to accumulate in the open disposal trenches while they were being filled, again promoting rapid waste degradation and settling. 
Certain specific characteristics of the disposal sites also contributed to the problems encountered. In some cases, the accumulation of water in the trenches due to the insiabiiity problem was aided by low-permeability soils, which enhanced the retention of witer in the trenches, and by sand lenses, which provided an avenue for water infiltration into the trenches from nearby surface areas. In one case, a permeab?e layer at the level of the bottom of the trenches served to condurt contaminated water away from the trenches and offsite.

Problems of thir kind have not been experienced at the three sites still in operation. Two of these sites, Richland, Washington and Beatty, Nevada are in arid or semi-arid environments and do not experience water management probiems. The site at Barnwell, South Carolina, which is in a humid environment, has not experienced water management problems for a number of reasons. Since the Barnwell facility was the last to open, the site berefitted from the experiences of the other ites. Specifically, the cap covering the disposal trenches is specially designed to minimize water infiltration. Surface sand layers surrounding the trenches are removed and compacted clay is added. Trenches also have sumps or sanpling purposes and monitoring trench water levels and may be used to remove accumulations of water if necessary. Sulface water management is also a key element by providing Jrainage away from trench areas and collection basins for surface run-off.

The three currently operating disposal sites did, however, have operational problems unrelated to site performance. In the fall of 1979 , after a series of incidents involving improperly packaged waste and damaged waste containers, the governors of Nevada and Washington temporarily closed the sites in those states. The governor of South Carolina, with the only operating disposal site in the east, began a two-year phase-down of the volume of waste accepted at the Barnweli site to $1.2 \mathrm{million} \mathrm{ft}^{3} / \mathrm{year}$. Although these actions were taken primarily to protect public health and safety, the governors also intended to demonstrate the need for more stringent enforcement of $1 \mathrm{ow}$-level waste regulations, and to signal their states' dissatisfaction with their status as hosts for the Naition's only disposal sites. 
The problems experienced in the developmental years of commercial lowlevel waste disposal led to the recognition that the regulations controlling the licensing of radioactive materials did not contain sufficient technical standards or criteria for the disposal of radioactive waste. More comprehensive standards, technical criteria, and licensing procedures were needed for the licensing of new disposal sites, the operation of the existing sites, and for the final closure and stabilization of all sites.

In December 1982, the NRC added a new part to Title 10 Code of Federal Regulations: Part 61, Licensing Requirements for Land Disposal of Radioactive Wastes (10 CFR 61). This regulation established a series of performance objectives and technical and financial requirements which a low-level waste disposal site and site operator must meet in order to ensure public health, safety, and long-term protection of the environment. The regulation established four performance objectives: (a) to protect the general population from releases of radioactivity, (b) to protect any individual who inadvertently enters a disposal site after the site is closed, (c) to protect workers during site operations, and (d) to ensure long-term stability at disposal sites to eliminate the need for ongoing active maintenance after closure.

Technical requirements were established for site selection, design, operation, and closure. Technical requirements were al so established for environmental monitoring, waste classification, and waste characteristics. These requirements included: (a) sites must have characteristics which maximize long-term stability and isolation of waste and ensure that performance objectives are met (site characteristics and performance must be evaluated for at least a 500-year period); (b) sites chosen for low-level radioactive waste disposal must be capable of being characterized, modeled, analyzed, and monitored; (c) the facility must be designed to provide for long-term isolation of the waste while minimizing the need for active maintenance after the site is closed; (d) monitoring systems must be capable of providing early warning of releases of radionuclides before they leave the 
site boundaries; and (e) to reduise subsidence or cracking sit the caps or barriers covering the waste, all low-level radioactive waste must be placed in the disposal unit in a way that maintains the integrity of the waste package and permits voids to be filled.

Special technical requirements were al so established for waste form. These requirements included: (a) waste must not be packaged for disposal in cardboard or fiberboard boxes; (b) liquid waste must be solidified or packaged $i: 1$ absorbent material; (c) wastes that generate toxic fumes or are spontaneousiy flammable or explosive are prohibited; (d) waste form or high integrity containers used to provide structural stability must maintain gross physical properties and identity for 300 years, under the expected disposal conditions; and (e) void spaces must be reduced to the extent practicable.

Tie three sited States passeu additional regulations to ensure that the transportation and packaging problems they had experienced would not be repeated. In general, these State regulations required radioactive waste shippers to: (a) purchase transportation permits and liability insurance, (b) certify that the shipment and transport vehicle have been inspected and comply with applicable State and Federal Laws, and (c) notify the disposal facility prior to shipment of waste. In addition, the regulations impose penalties ranging from $\$ 1000$ to $\$ 25,000$ in fines and possible suspension or revocation of the permit.

\section{State Involvement, $1980-1990$}

By 1980 , it appeared that private industry would not be able to develop new disposal facilities without the participation of government, in spite of the regulatory reforms that were underway at the time. In December of that year, Congress passed the Low-Level Radioactive Waste Policy Act (PL. 96-573). The Act (amended in 1985 by the Low-Level Radioactive Waste Policy Amendments Act) encouraged States to form regional compacts for disposal of low-level waste and provided that such compacts approved by Congress would be able to limit use of their disposal sites to low-level waste generated within their respective regions, beginning January $1,1986$. 
At the time the 1980 Act was passed, the National Governors' Association, the National Conference of State Legislatures, and the State Planning Council (a study group that included State and local officials), and other groups supported State responsibility for disposal of low-level waste. These groups believed that State participation in the development of disposal capacity for low-level waste disposal wou?d ensure a higher level of surveillance by local officials and the public than would be the case if the private sector alone were left to establish new disposal sites.

Although the steps in establishing a new disposal facility are essentially the same as they were in the early days of site development (site selection, site characterization, license preparation, license review, operations, closure and post-closure care), each of these steps is far more extensive and is conducted under much closer public scrutiny.

In addition to the general requirements in 10 CFR 61, States have established siting requirements specific to each State's particular needs and circumstances. These include hydrogeological factors, environmental and public health factors, natural and cultural resources, socioeconomic factors, local land uses, transportation considerations, and aesthetic factors.

States have flexibility as to the approaches they use in selecting disposal sites. Generally, a geographic overlay nrocess is used to eliminate large tracts of 1 and from further consideration or to identify locations that may be suitable for a disposal site. For purposes of efficiency, site screenings generally use a phased approach, first applying data which is readily and uniformly available across the entire study area. By first eliminating areas that can easily be shown not to be qualified for a disposal site, subsequent phases of the screening, for which data may be more difficult to obtain, can be focused upon smaller land units. Upon exhausting all available data that can be applied in a map screening process, area visits by teams of specialists are usually necessary in order to identify local features that qualify or disqualify specific areas. 
Two kinds of criteria generaliy are used in screenings, exciusionary and avoidance. (The names may vary.) Areas that include exclusionary factors are eliminated from further consideration. The effect of avoidance criteria on an area is cumulative, so that an area may be eliminated if it exhibits a number of avoidance characteristics. This involves development of formulas that require each avoidance criteria to be given an assigned numerical value based on its importance to the screening process. (Screening may also be conducted using "favorability" criteria to identify eligible areas, rather than using avoidance criteria to eliminate ineligible areas. Because favorability criteria are the converse of avoidance criteria, the practical effect on site identification is the same.)

The varying approaches taken by States results from differing prescriptions in State siting laws, different ways to apply the gianeral requirements of 10 CFR 61 , and different methodologies used by States in the site selection process.

Once a preferred site is identified for further evaluation, site characterization is conducted to support the license application in demonstrating that the facility will be able to isolate the waste while it decays to near background levels. Detailed studies are conducted on the ecology, air quality, land use, cultural resources, and potential socioeconomic impacts of the site on neighboring communities. Tiis information, along with institutional, inancial, and general information on the applicant, is included in the disposal facility license application that is submitted to the Nuclear Regulatory Commission or State agency for review. The disposal facility license applicatic: for the Southwestern Compact's regioilal disposal site in California (the first license application submitted under the requirements of 10 CFR 6i) included approximately 8000 pages of data, information, and analysis.

Review of the license application is equally extensive. In 1988, the NRC estimated that its review of a license application submitted under 10 CFR Part 61 would require a minimum of 416 staff-weeks across 21 different disciplines (NUREG-1274, August 1987). 
As part of the license application review, the proposed environmental monitoring plan and site closure plan are closely scrutinized. An environmental monitoring plan must be established for the preoperational, operational, and postoperational periods of the disposal site. At a minimum, the monitoring program must be able to: (a) provide adequate data for the evaluation of potential long-term health and environmental effects resulting from accidental or routine exposure conditions; (b) provide early warning of releases of radionuclides from the disposal site before they leave the site boundary; and (c) define those protective and restorative actions to be taken if an unplanned release of pollutants were to occur from the site.

The site closure plan should describe how the facility will be closed and stabilized. In general, the plan must demonstrate that the disposal site will be closed and controlled after -losure so that exposures to humans are within the limits established in 10 CFR 61. The closure plan must also demonstrate that closure of the facility will be done in such a way as to ensure protection of any individual inadvertently intruding into the disposal site and occupying the site or contacting the waste at any time after active institutional controls are removed. In addition, the plan must demonstrate that the facility will be closed in order to achieve long-term stability of the disposal site and to eliminate, to the extent practicable, the need for ongoing active maintenance so that only surveillance, monitoring, or minor custodial care is required.

Lessons learned during the developmental years of commercial low-level waste disposal led to regulatory reform of the system under which disposal is conducted. Improvements in the form of waste that is disposed of, as well as in site selection, characturization, operations, monitoring and postclosure care, have significantly reduced the likelihood that a new low-level radioactive waste disposal facility will require costly remediation in the future.

In addition to these technical improvements, many States and compacts have also imposed requirements for additional engineered barriers (generally concrete waste packages or disposal cells) to reinforce public confidence that 
the waste will be safely isclated from the environment while it decays to background levels. Although the long-term benefit of engineered barriers over carefully selected natural barriers is a topic of much discussion and technical analysis, the selection of multiple barrier systems illustrates the degree to which State and compact officials have responded to public concerns that disposal of low-level radioactive waste should pose as little risk to public health and safety as reasonably possible. 
PART TWO

HISTORIES OF SIX LOW-LEVEL RADIOACTIVE WASTE DISPOSAL FACILITIES

\section{Beatty, Nevada}

The Beatty low-level radioactive wasto disposal facility was the first commercially operated radioactive waste disposal facility to be licensed by the U.S. Atomic Energy Commission (AEC), now the Nuclear Regulatory Commission $(N R C)$. The Beatty site is located on the Amargosa Desert in Nye County, on 7 and owned by the State of Nevada. The disposal site is on an 80-acre tract approximately 11 miles south of the town of Beatty and 105 miles northwest of Las Vegas.

\section{Site Description}

The Amargosa Desert region where the site is located is part of the Basin and Range Province, which is characterized by relatively barren mountain ranges and broad, relatively flat valleys. The site is located on unconsolidated deposits of alluvial sand, clay, silt, and gravel approximately $600 \mathrm{ft}$ thick, formed by weathering action on the adjacent mountain ranges (Figure 2). Underlain by folded metamorphic and sedimentary bedrock, the site surface is approximately $2800 \mathrm{ft}$ above sea level. A regional groundwater table lies at a depth between 260 and $330 \mathrm{ft}$ below the surface in the alluvial soils.

An intermittent river, the Amargosa River, lies five miles from the site and serves as the principal drainage channel in the area. There is no source of perennial surface water within 10 miles of the site.

The climate at the site is arid, with an average annual rainfall varying from 2.5 to 5.0 inches and a potential evaporation rate of approximately 100 inches per year.

The low-level waste disposal facility is adjacent to a chemical waste disposal facility, which is separated from the low-level waste facility by a 


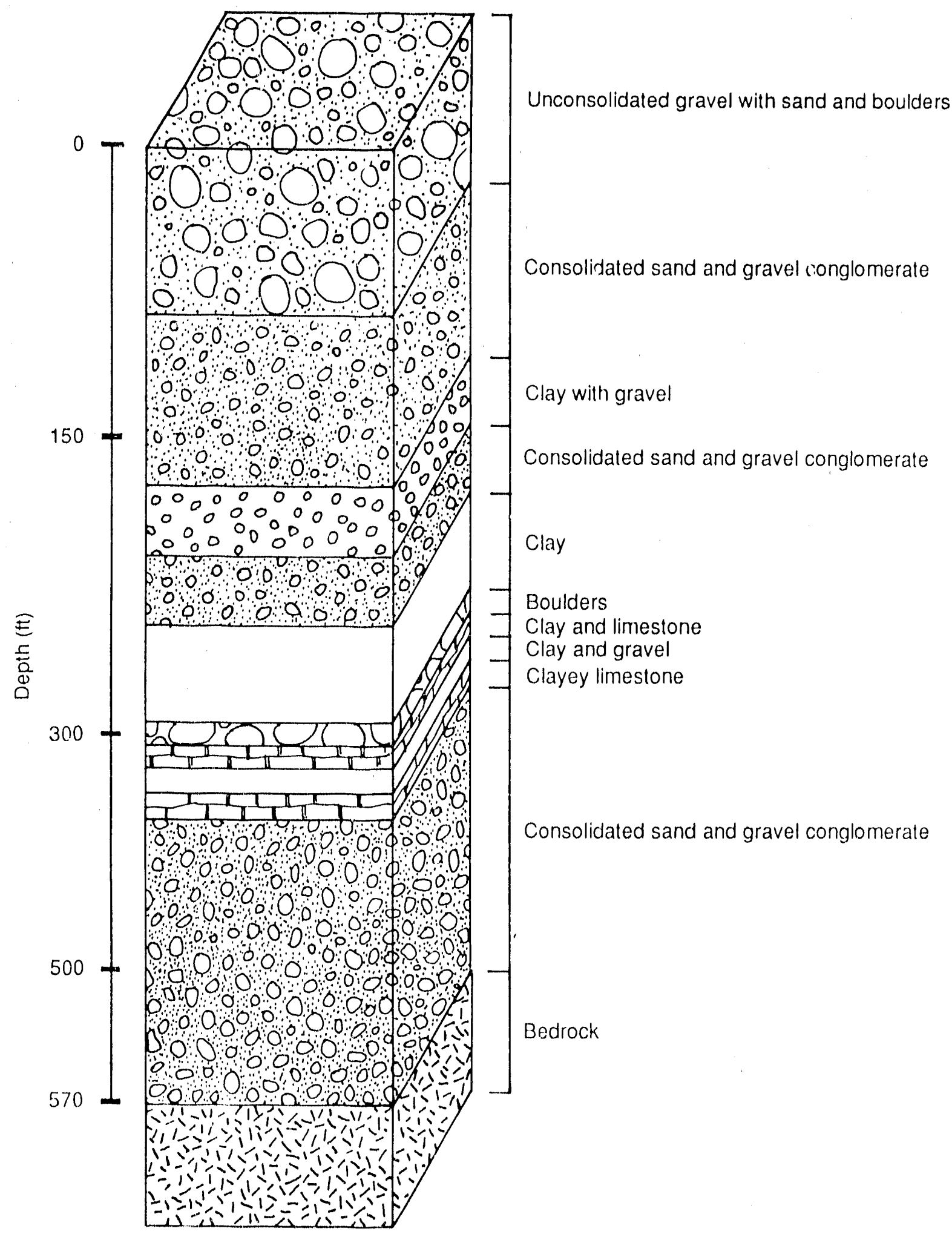

Figure 2. Beatty, Nevada disposal site geology. $\quad 0.3039$ 
buffer zone, which is in turn, a minimum of $200 \mathrm{ft}$ wide. A security ience also separates the two facilities.

The low-level waste disposal site ccnsists of 22 trenches of varying dimensions, ranging from 300 to $800 \mathrm{ft}$ in length, 4 to $350 \mathrm{ft}$ in width, and 6 to $50 \mathrm{ft}$ in depth (Figure 3). The trenches constructed in recent years have tended toward the larger dimensiuns.

\section{Operating History}

The Beatty facility, which opened in September 1962, is still in operation. The first licensed uperator of the site was California Nuclear, Inc. In March of 1968, the assets of the company were transferred to Nuclear Engireering Company (NECO), which in 1981 changed its name to US Ecology, Inc. US Ecology is the site operator today.

Low-level radioactive waste is disposed of at Beatty primarily by shallow-land burial. Trenches are constructed with converitional earth-moving equipment, following a cut-and-cover procedure. Because of the high stability of the local soil, trenches typically are cut with nearly vertical side slopes, maximizing the space available for waste disposal. Waste packages have generally been emplaced in an orderly manner, using either a crane or forklift. Waste-transport vehicles are driven down ramps and the waste is unloaded directly into the larger trenches. In the older trenches, waste was placed in the trench to within $3 \mathrm{ft}$ of the ground surface. In the future, the waste will be placed to a minimum of $8 \mathrm{ft}$ under ground. The trench cover will be mounded over the waste to a vertical centerline elevation of at least $2 \mathrm{ft}$ above the surrounding ground surface. Thus, the center surface of the trench cover will be at least $10 \mathrm{ft}$ above the waste. The completed trench is identified by permanent concrete posts marked with the trench number, dates opened and closed, trench boundary coordinates, and waste characteristics (i.e., total volume and activity, as well as the quantity of source and special nuclear materials). Trench bouidaries are located by an engineering survey referenced to benchmarks. 


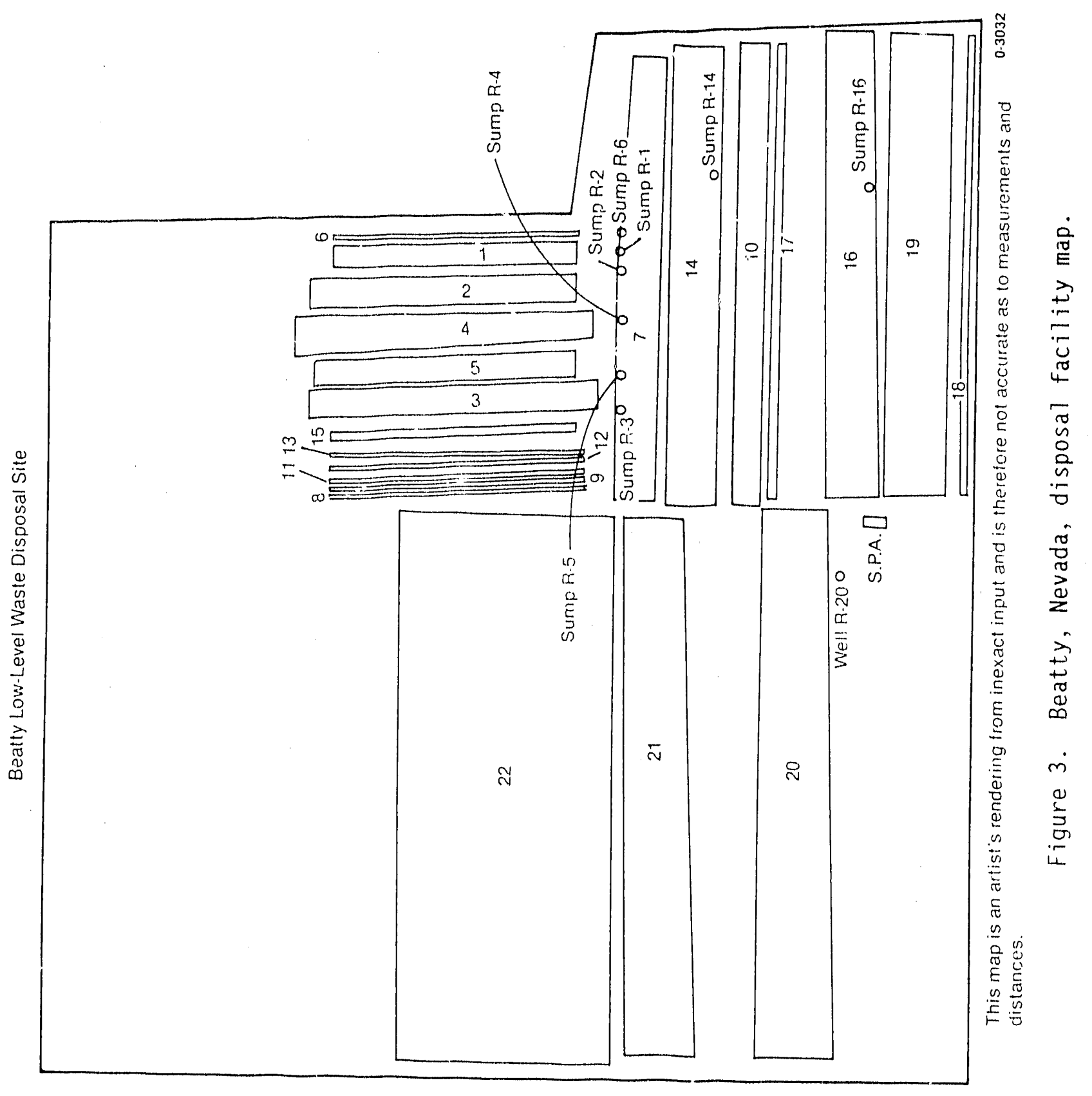


From startup in 1962 through 1989, approximately 4 million $\mathrm{ft}^{3}$ of waste had been buried at Beatty (Table 1). This waste contained about 500,000 curies of bypruduct material, 2.9 million $1 \mathrm{~b}$ of source material, and $6001 \mathrm{~b}$ of special nuclear material.

There have been no problems with perfc, mance of the disposal facility. Difficulties that were experienced wore unrelated to the ability of the site to isolate radioactive waste. Problems were encountered in 1976 when it was discovered that site employees had removed a cement nixer and various tools, hardware, and building materials which had been brought on site as radioactive waste. These materials were lised by the site employees in local construction projects. The NRC and State of Nevada suspended US Ecology's operating license until the contaminated materials were recovered and residual radioactivity was removed. The company terminated all the employees who were responsible for the violations and a new site manager was brought in to manage Beatty.

Between March 1976 and December 1979, a series of events involving improper handling and packaging of low-level waste resulted in the closing of the site for intervals because the operator's license was temporarily suspended. The site was reopened only after assur "ice was given by the Federal Government that the rules governing shipments of low-level waste would be enforced. At the same time, a permitting system for waste shipments was established.

\section{Facility Status}

The Beatty site continues to dispose of low-level waste under the management of US Ecology, Inc. However, the additional regulatory and license requirements, instituted as a result of the operational difficulties previously encountered, have tighten'ed State and management controls. The major change has been the institution of a third-party inspection system in April 1981, which all generators shipping to Beatty are required to accept as a condition for receiving a permit to use the disposal site. Under the inspection system, which is conducted by a contractor to the State, permits 
are issued only after an initial onsite audit is performed to verify the generator's compliance with Federal and State regulations and with the disposal facility license requirements. (The inspection contractor also does follow-up, unannounced audits of the permitted generator.) Administrative fines of up to $\$ 20,000$ per incident, suspension of permits, and criminal penalties could result from permit infractions.

Nevada became a member of the Rocky Mountain Interstate compact in 1985. As one of the three sited States, Nevada is obligated to allow the Beatty facility to dispose of wastes generated outside the compact through 1992, as long as the States in which the generators are located continue to meet the milestones prescribed in the Low-Level Radioactive Waste Policy Amendments Act (LLRWPAA) of 1985. The LLRWPAA of 1985, however, limits the amount of waste Beatty is required to accept to 1.4 million $\mathrm{ft}^{3}$ during the seven year period (as based on an average annual volume of $200,000 \mathrm{ft}^{3}$ per year).

Because of the low volume of waste received at Beatty, unit disposal costs have increased considerably in recent years, with the 1988 basic rate being $\$ 30.11 / \mathrm{ft}^{3}$. This fee, among other things, includes a $\$ 2 / \mathrm{ft}^{3}$ charge which is deposited in the site's long-term care and maintenance fund. Additional charges include a $\$ 40 / \mathrm{ft}^{3}$ surcharge on non-Rocky Mountain Compact waste.

The Beatty site operator, US Ecology, Inc., and the State of Nevada, monitor the concentrations of radioactivity in groundwater in both onsite and offsite wells and in air, soil, and vegetation on a quarterly basis. Records of the measured concentrations are maintained. This monitoring has not shown evidence of migration of radioactivity from the disposal trenches through any environmentai pathways.

\section{The Future}

The Beatty disposal facility is scheduled to close by December 31, 1992 , in accordance with an agreement between the Governor of Nevada and the Rocky Mountain Compact Board. The Compact Board has designated Colorado to assume 
responsibility for the compacts's low-level waste disposal. Colorado has adopted siting legislation, and the State Geologic Survey has completed an initial study of the entire state. The study indicates that six areas of the State appear suitable for further investigation.

US Ecology, Inc. has submitted a proposed site stabilization and closure plan for the commercial low-level waste disposal facility. This document provides site-specific requirements to ensure that the facility is closed in accordance with the site's license and the lease agreement between the State of Nevada and US Ecology, Inc. The purpose of this plan is to ensure that the waste disposed of during the operational phase of the facility continues to remain in a suitable, stable, and safe condition after site closure. 


\section{Maxey Flats, Kentucky}

The Maxey Flats low-level radioactive waste disposal site is located about nine miles northwest of Morehead, Kentucky, 65 miles northeast of Lexington, Kentucky, arid 200 miles southeast of Cincinnati, Ohio. The 280-acre site is owned by the Commonwealth of Kentucky. The site was opened under a lease arrangement between the State of Kentucky and Nuclear Engineering Company (now U.S. Ecology, Inc.), of Louisville, Kentucky in January 1963. U.S. Ecology, Inc. operated Maxey Flats until December 1977, at which time commercial operations were terminated. The disposal site nas remained closed since that date.

\section{Site Description}

Surface soils at the site generally consist of light-brown silty clay, ranging in depth from 1 to $10 \mathrm{ft}$. In most areas of the disposal site, this cover layer is terminated by a thin layer (18 to 24 inches) of siltstone or very fine sandstone, which is directly underlain by shale, siltstone, and sandstone (Figure 4). The trenches lie entirely within the Nancy member of the Borden Geologic Formation. The Nancy member is a green shais that manifests plastic behavior when wet, and which is interlain with silistone and sandstone. It is an aquitard, having low permeability, and contains isulated groundwater in the soil zone at a depth of 3 to $6 \mathrm{ft}$. There is a continuuus groundwater table at a depth of 30 to $50 \mathrm{ft}$, but no regional aquifer is in the area. Groundwater migration occurs primarily through shale fractures and interlinking sandstone beds.

The ridge area where the site is located slopes off sharply on three sides. The area is drained on three sides: to the east by a perennial stream, No-Name Creek, which collects about $75 \%$ of the surface runoff; to the west by Drip Springs Hollow Creek; and to the south by Rock Lick Creek. The drainage from these tributaries flows into Fox Creek and then into the Licking River. The site is in a humid region, with rainfall varying by season, but most abundant in spring and early summer. The average annual rainfall in the region is 46 inches. 
The disposal site currently consists of 52 trenches, a number of hot wells, and several special pits (Figure 5). The trenches vary considerably in size, ranging from 150 to $680 \mathrm{ft}$ in length, 10 to $75 \mathrm{ft}$ in width, and 9 to $30 \mathrm{ft}$ in depth. The floor of each trench slopes at one degree toward a sump constructed at the low end to permit water collection and removal. The hot wells are lined, variable in size (generally $15 \mathrm{ft}$ deep and several feet in diameter), and capped with concrete. The hot wells were used to dispose of high-activity gamma sources. The special pits, which vary from 15 to $75 \mathrm{ft}$ in length, 9 to $25 \mathrm{ft}$ in width, and 5 to $15 \mathrm{ft}$ in depth, were used to dispose of large volumes of higher activity waste, such as spent resins from power reactors.

\section{Operating History}

Maxey flats was opened as a commercial disposal site to service the growing nuclear utility and industrial waste-generation market in the southeast and middle-Atlantic States, and as a vehicle for Kentucky to enccurage a commercial nuclear energy program.

Trenches were excavated to full size before emplacement of waste containers began. After being logged in and surveyed, the waste containers were placed into the trench, beginning at one end. A crane was used to emplace large items and those casks having high surface radiation levels. When the trench was filled with waste, it was covered with a minimum of $3 \mathrm{ft}$ of clayey soil, applied in compacted layers. A mounded cap was developed over each trench to enhance water runoff, and a layer of topsoil (2 to $3 \mathrm{ft}$ ) was added to support a vegetative cover. The completed trench was marked with a monument, placed at one end, on which the trench number and date of closure were recorded. Disposal records locating the trench boundaries and providing data on total volumes and radioactivity content of the trench are keyed to tre monument. However, recent work at the site indicates that disposal records and trench monuments are not always accurate. 


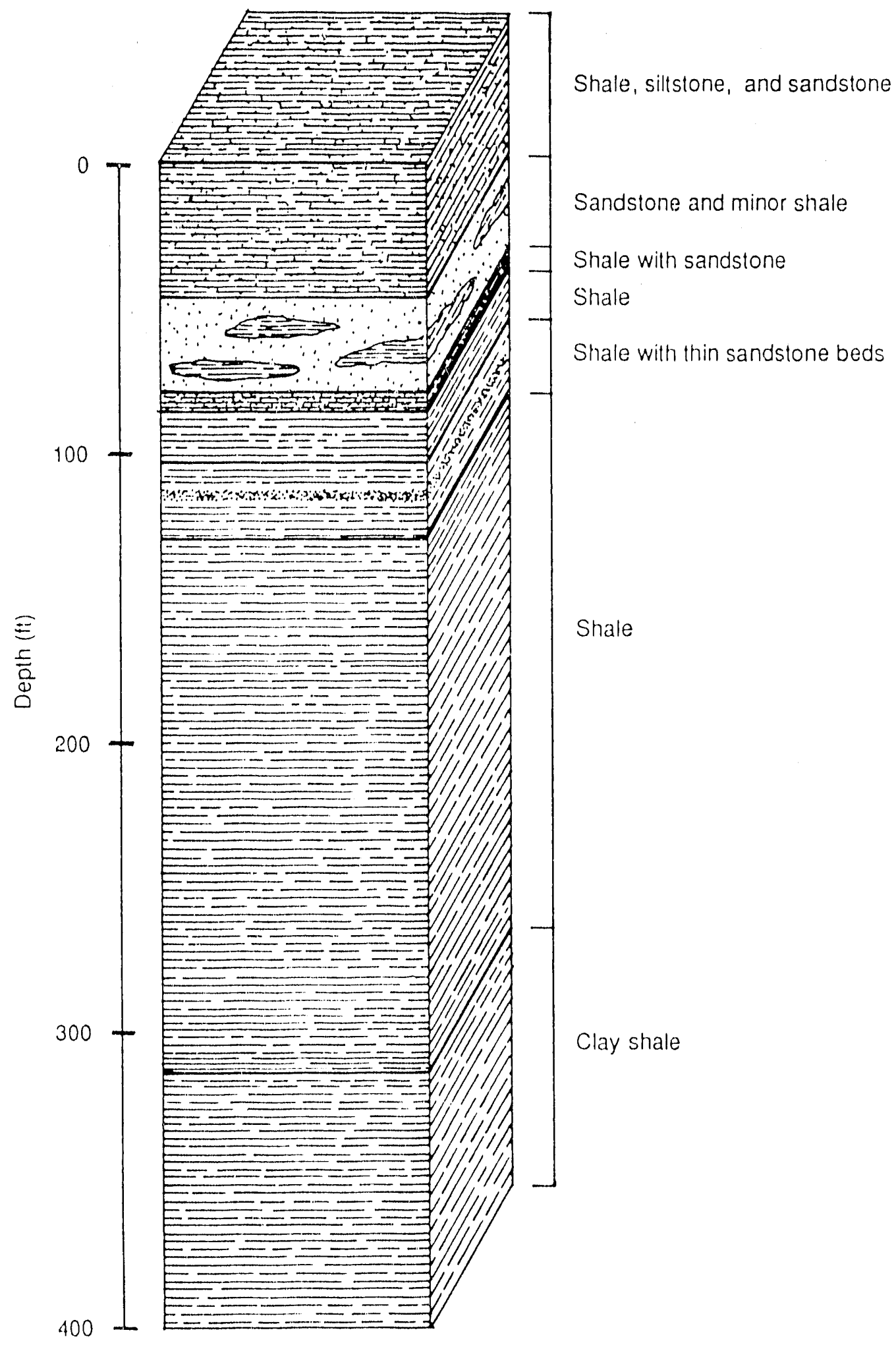

Figure 4. Maxey Flats, Kentucky, disposal facility site geology. 


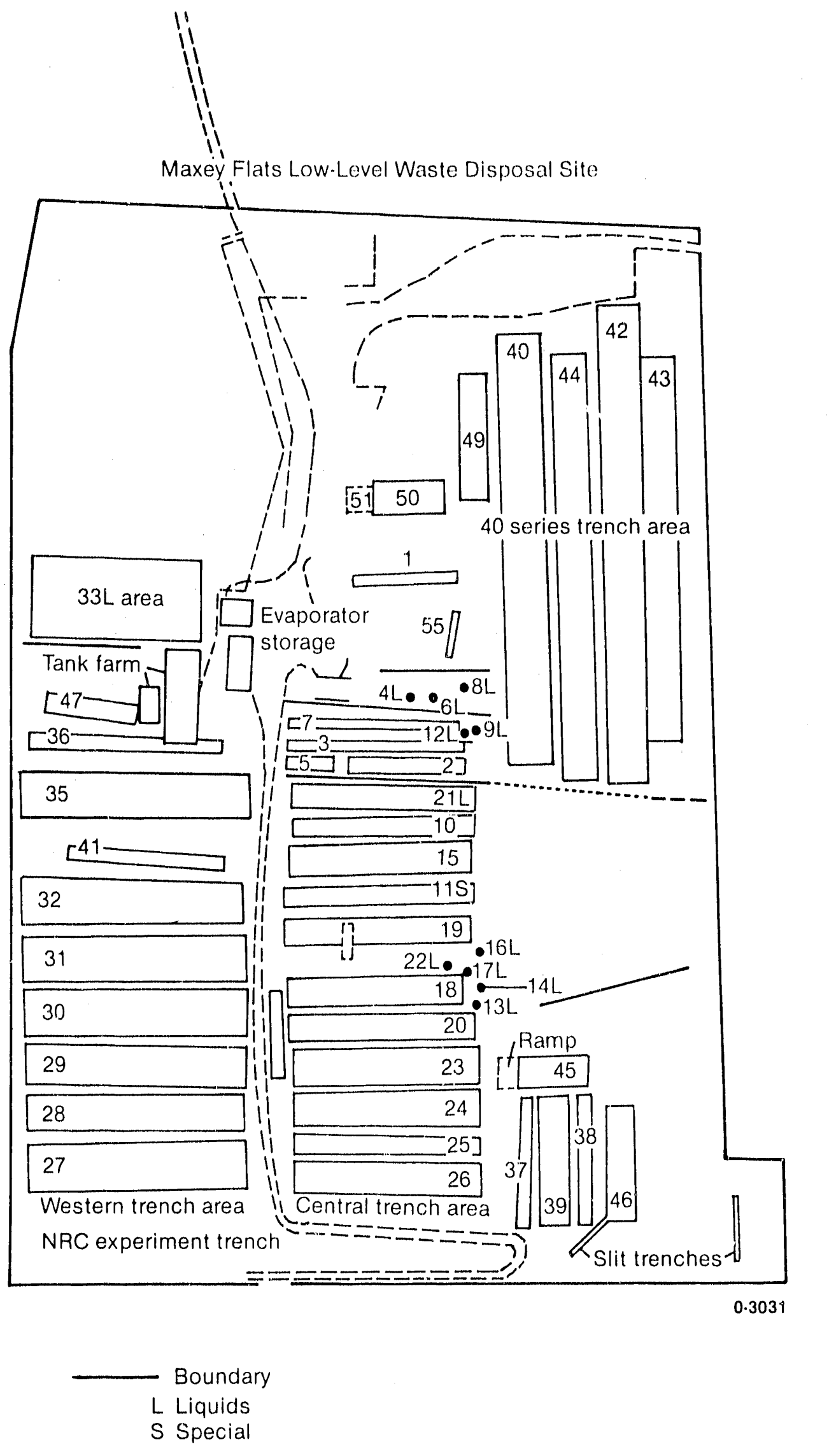

Figure 5. Maxey Flats, Kentucky, disposal facility map. 
Before it was closed, Maxey $\mathrm{Flais}$ became the largest commercial repository for low-level waste in the nation, and still contains a significant fraction of all the commercially generated low-level radioactive waste buried in the United States. During the period between startup in 1963 and closure in 1977, over 4.7 million $\mathrm{ft}^{3}$ of waste were buried at Maxey Flats (Table 1). This waste contained about 2.4 million curies of byproduct material, $533,000 \mathrm{lb}$ of source material, and $950 \mathrm{lb}$ of special nuclear material.

Tritium ( $H-3$ ) was probably the most abundant radionuclide in tra trenches (see discussion on radioactive decay in Appendix $A$ ), although site records are not sufficiently complete to permit an exact determination. It is estimated that 176 lb of plutonium-239, plus other plutonium isotopes, have been buried at the site.

Subsidence, water management problems, and the resulting migration of radioactivity in the area of the site caused a growing public and official concern through the early to mid-1970s. In the early 1970s, a significant amount of water accumulated in the disposal trenches. This water accumulated as a result of both a high rate of precipitation and a greater rate of infiltration into the trenches than out of them, the bathtub effect. In 1973, Kentucky required Nuclear Engineering Company to initiate a water management program. This program, conducted first by the Nuclear Engineering Company and later by the Commonwealth, continued until mid 1980. The program involved pumping the contaminated water from the trenches to aboveground holding tanks, treating the water to remove radioactivity, evaporating the treated water, and transferring the residual material to storage tanks to hold for eventual disposal. The evaporator effluent, although controlled by dilution of trench liquid to ensure that environmental releases were below allowable NRC standards, represented a source of offsite radioactivity because it contributed to surface contamination through dispersal of the plume in the vicinity of the site. Furthermore, site management and disposal practices in the operating period before 1972 probably contributed other potential sources of surface contamination from accidental spillage of waste, direct disposal of contaminated liquids on the slopes of the site, and dispersal of liquid from the trenches by earth-moving equipment. 
Improvements in maintenance operations were undertaken at the facility to reduce the i ikelihood that water would contact the buried waste. In late 1981, a flexible membrane liner was installed as a surface cover over the trench area and associated surface drains to direct as much surface water away form the trenches as possible into defined surface drainageways and then off site. This action was significant in the reduction of radioactive miterial release from the site due to surface influences. Other actions included grading and improving surface drainage, recapping older trenches to reduce permeability, and improving procedures for capping new trenches. According to one Kentucky official, these efforts, plus the removal of several aress of surface contamination, appear to have been effective in reducing the release of radioactivity.

\section{Basis for Facility Closure}

The site was closed in December of 1977 after lateral seepage of radionuclides into an adjacent, newly coristructed trench was detected. This flow was along a sandstone bed about 25 feet below ground surface. This bed formed the bottom of most of the trenches and was serving as a conduit for leachate migration from the site.

\section{Post-Closure History}

In May 1978, the Commonwealth, after negotiating the purchase of the site operator's leasehold right and equipment, assumed control of the siie. The Kentucky Finance and Administration Cabinet was placed in charge of stabilizing the facility. In February 1979, the Finance Cabinet delegaied to the Natural Resources and Environmental Protection Cabinet the responsibility of managing the site.

Post-closure maintenance of the site was performed by US Ecology, Inc., under contract with Kentucky until 1979, at which time National Waste Management Services of Lexingion, Kentucky, a subsidiary of Dames \& Moore, Inc., was selected to maintain the site. Natiorial Waste Management Services continued to provide the necessary support services at Maxey Flats through 
Iune 1981 to maintain the site in its shutdown state. Kentucky then selected Hittman Nuclear Development Corporation of Columbia, Maryland, to maintain the closed site.

Routine environmental monitoring and special investigations during this period revealed elevated lovels of tritium in the surface water, groundwater, and vegetation from the west hillside of the Maxey Flats Disposal Site. In particular, two trees which had much higher than normal concentrations of tritium in their leaves were identified on the west hillside. In 1983, the Kentucky Cabinet for Human Resources undertook a program to identify the source of the tritium in the trees on the west hillside. The results of the investigations demonstrated that trench leachate had moved from the trenches to the west hillside along the lower sandstone bed. Sampling indicated that the leachate was present outside the controlled area and presented a potential for both pollutants and radionuclides to migrate from the site to the local environment. In consideration of the potential health impacts the migration might present, a decision was made to pursue remediation via the Environmental Protection Agency (EPA) Superfund process.

\section{Facility Status}

In 1986, the EPA notified 832 parties that Maxey Flats had been designated a Superfund site. Each of these parties was designated a Potentially Responsible Party in any corrective actions. These parties include federal agencies, federal contractors, medical facilities, physicians, clinics, industry, state agencies, transporters, broker/haulers, and the land owner and site operator. Currently, a Remedia? Investigation and Feasibility Study (RI/FS) is being conducted to identify problams at the site and to develop and evaluate remedial alternatives. Once the RI/FS is complete, the EPA will issue a Record of Decision (ROD) that will identify the selected remediation approach. Once the remedial alternative has been selected, the Potentia: Responsible Parties will design and implement the selected alternative. 
In June 1989, the EPA began an immediate removal action of the liquid radioactive material stored in the aboveground tanks. Approximately 280,000 gallons of radioactively contaminated liquids were solidified in a cement matrix. The cement matrix was then formed into large blocks. A state-of-the-art trench is to be coistructed on site in the fall of 1990 and the blocks permanently disposed of in the trench. The EPA utilized their superfund contractors to perform this work. 


\section{West Valley, New York}

The Western New York Nuclear Service Center was established to encourage development of nuclear technologies in the northeast United States. The major facilities at the Nuclear Service Center include: (a) the only commercial nuclear fuel reprocessing plant that ever operated in the nation; (b) a spent fuel receiving and storage facility; (c) a high-level liquid waste storage facility; (d) a 7-acre waste disposal ground used primarily to dispose of solid, long-lived waste such as spent fuel hardware; and (e) a commercial low-level waste disposal site. This report addresses only the commercial low-level waste disposal site.

The Nuclear Service Center is a 3345-acre site located about 30 miles southeast of Buffalo, New York, in a rural area near the small community of West Valley. In February 1982, the Department of Energy took possession of most facilities at the Center for the purpose of carrying out the west Valley Demonstration Project. The State-owned commercial low-level radioactive waste disposal site is currently under the custody of the New York State Energy Research and Development Authority (Energy Authority). The West Valley disposal site, opened as a commercial veniure in 1963, was operated by Nuclear Fuel Services under a lease arrangement with the State of New York until March 1975. At that time, operations were suspended after an overflow of contaminated water was detected from two of the disposal trenches. The disposal site has remained closed since that date.

\section{Site Description}

The dispc:al facility is located on a plateau near the middle of the Nuclear Service Center. The location of the disposal site was selected because of its good surface drainage, the absence of any near-surface aquifers, and the low permeability and high adsorptive capacity of its soil. The soil where the disposal area is located (Figure 6) consists of a top layer (10 to $12 \mathrm{ft}$ ) of weathered till (which is a brown, firm, silty clay containing bits of gravel and rock) overlying a layer (150 to $300 \mathrm{ft}$ ) of unweathered till (a gray, plastic, silty clay having scattered rock fragments and pebbles). An 
Upper Devonian Shale of the Canadaway Group is the bedrock underlying the tills at the site. It is a moderately hard shale and siltstone which may attain a thickness of $500 \mathrm{ft}$ or more beneath the disposal area. The surface water in the vicinity of the disposal area consists of Frank's Creek on the east side, Erdman Brook on the north side, and ar unnamed tributary on the northwest side, which join to the northeast of this area.

The site consists of two distinct sets of parallel tienches, identified as the north and south disposal areas (Figure 7). The northern area, used during the 1963 to 1969 time period, consists of five long trenches numbered 1 to 5 and two "special" trenches numbered 6 and 7 . Trenches 1 through 5 are nominally $30 \mathrm{ft}$ wide, $20 \mathrm{ft}$ deep, and $600 \mathrm{ft}$ long. The distance between trenches is 4 to $6 \mathrm{ft}$; however, due to the method of construction (bulldozer excavation) and instances of wall collapse, some trenches are believed to be connected. The trenches were originally covered with a 4-ft cap; in 1978 an additional $4 \mathrm{ft}$ of cover was added. Trench 7 is a narrow, shallow concrete vault in which wastes were disposed and trench 6 is actually a series of holes for the disposal of high-activity wastes requiring immediate shielding.

The southern area was developed between 1969 and 1975. This area also consists of seven trenches (numbered 8 to 14 ) that are typically $30 \mathrm{ft}$ wide, $20 \mathrm{ft}$ deep, and $600 \mathrm{ft}$ long. During development of this area, a number of changes in construction and disposal practices were incorporated as a result of the experience gained from the northern area. Among other things, the separation distance beiween trenches was increased to $10 \mathrm{ft}$, trench floors were sloped, and cap thickness was increased to $8 \mathrm{ft}$. Waste was emplaced beginning at the shallow end of the trench and proceeding to the deeper end. This allowed precipitation which entered the trenches during construction and filling to drain away from the waste and collect at the lower end of the trench. From there, the infiltrate was pumped to two lagoons located adjacent to the northern trenches. These lagoons are now filled with earth. A third lagoon for pumped-out trench water was constructed adjacent to the southern trenches in 1975. 


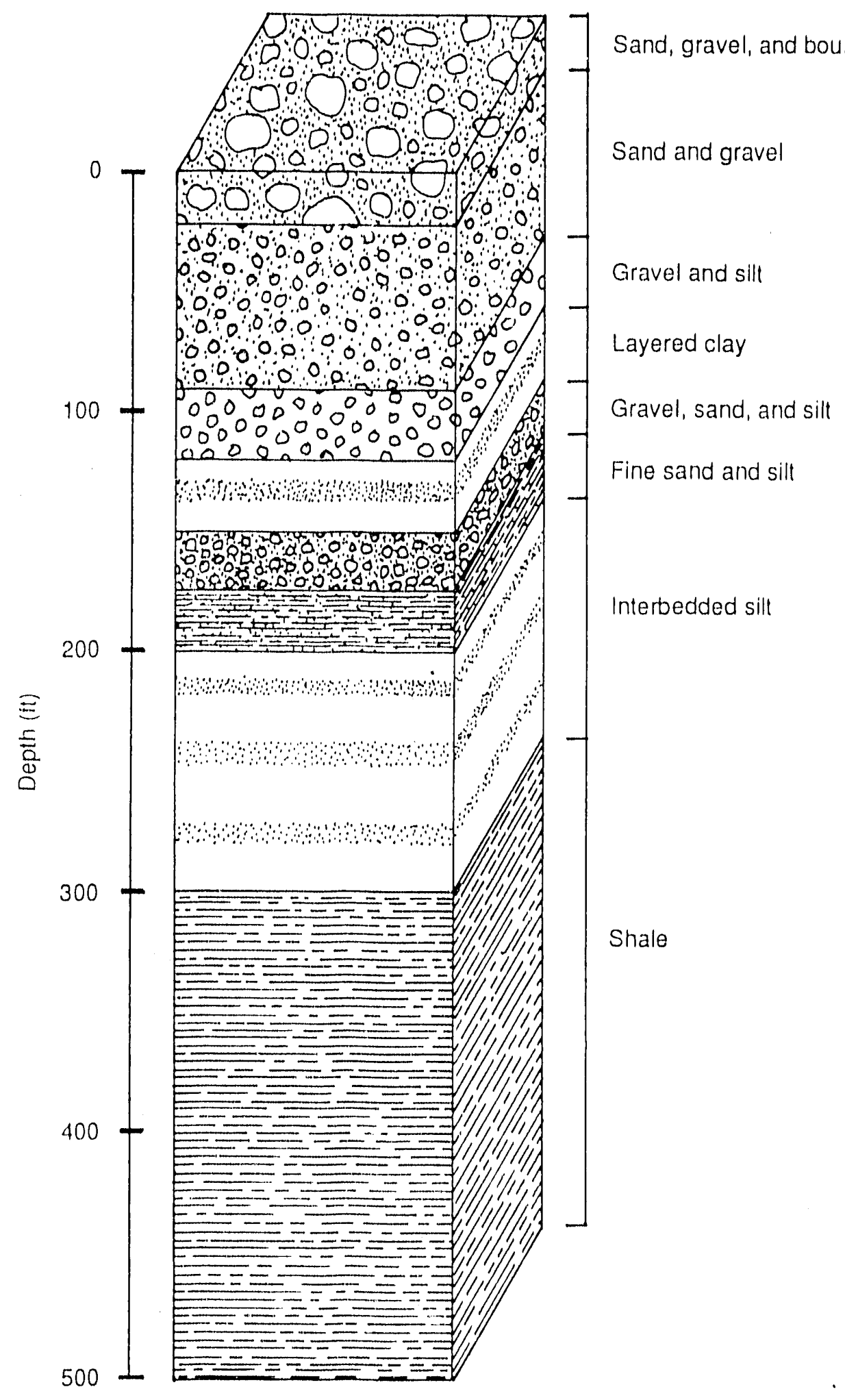

Figure 6. West Valley, New York, disposal facility site geology. 


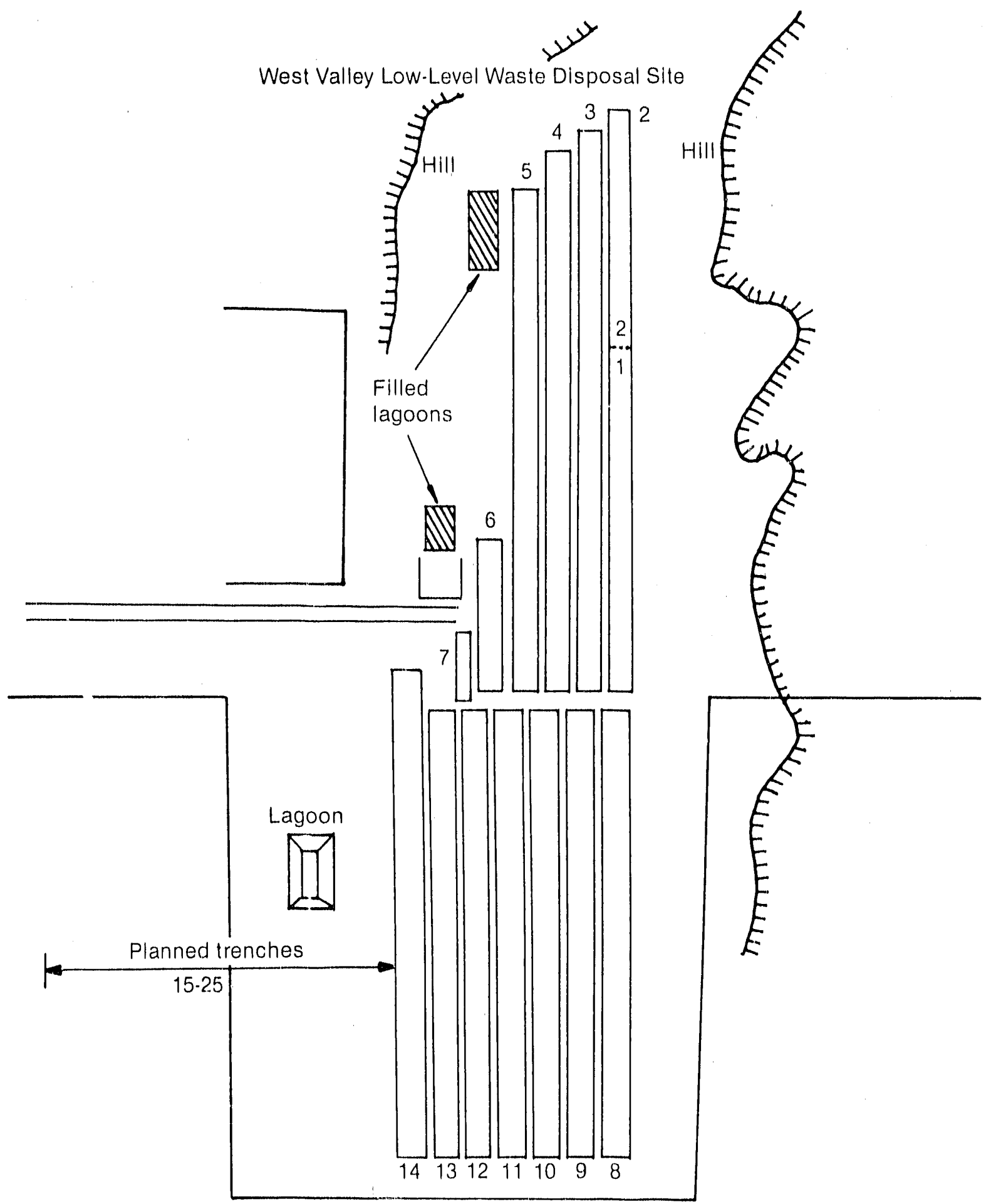

This map is an artist's rendering from inexact input and is therefore not accurate as to measurements and distancer

Figure 7. West Valley, New York, disposal facility map. 0.3028 
Operating History

The 22-acre commercial disposal site was established as a natural outgrowth of other nuclear activities. It satisfied the need for disposal capacity for the nuclear facilities, industries, and institutions that generated solid radioactive waste in the northeast and middle-Atlantic States, and at the same time provided for the disposal of the low-level waste generated by the nearby reprocessing plant.

The disposal trenches were excavated in segments as needed, depending on the rate of waste accumulation. The waste containers were placed in the trenches primarily by hand, with the majority of the containers stacked in a horizontal position. Heavy containers or those with high surface radiation levels were emplaced by means of a crane. After each section of a trench was filled, it was covered with soil, initially to a minimum cap thickness of $4 \mathrm{ft}$ and, after 1968, to a minimum thickness of $8 \mathrm{ft}$. Trenches numbered 1 through 7 had $4 \mathrm{ft}$ of cap cover until 1978, when an additional 4 - ft cover was added.

Disposal records indicate that, during the years the disposal facility operated, 2.4 million $\mathrm{ft}^{3}$ of waste were disposed of (Table 1). This waste contained about 1.3 million curies of byproduct material, 1 million $1 \mathrm{~b}$ of source material, and $125 \mathrm{lb}$ of special nuclear material. Tritium (H-3) was the most abundant radionuclide present with a total of 106,000 curies being buried (see Appendix A for a discussion of radioactive decay). Of the special nuclear materials accepted for disposal, approximately 35,000 curies of plutonium-238 were disposed before the State stopped this practice in 1973 .

\section{Basis for Facility Closure}

Routine monitoring of the disposal trenches showed that water had accumulated in the trenches during the first 2 to 3 years after each trench was covered and tien remained constant, with the exception of Trenches 3, 4, and 5. The water in Trenches 3, 4, and 5 continued to rise until March 1975, when it reached the original soil surface level and seeped through the covers of Trenches 4 and 5, flowing at a rate of approximately 1 gallon per day. 
Nuclear Fuel Services stopped disposal operations when the seepage was discovered and agreed that disposal operations would not resume until all New York State Department of Environmental Conservation requirements for reopening the disposal area were met. No waste has been buried in this facility since that time, although subsequent corrective measures have been taken to minimize the amount of water infiltrating into the trenches.

\section{Post-Closure History}

Following a study of the trench water problem and possible corrective actions, a trench cap rehabilitation program was conducted. Based on experience with the southern trenches, it was believed that 8 -ft-thick trench caps would prevent infiltration of water. Consequently, in the summer of 1978, an additional $4 \mathrm{ft}$ of compacted silty till was placed on top of Trenches 1 to 5 and suriace drainage improvements were made.

Shortly after the trench cap rehabilitation, sharp increases in water levels in Trenches 11 to 14 in the south disposal area were measured. These increases were attributed to an extended dry summer period that caused desiccation cracking in the cover. Corrective actions, taken in the fall of 1980, included removing 24 inches of till and 6 inches of topsoil from the trench covers, placing and compacting a new 28-inch layer of till in sublayers, and adding 12 inches of topsoil. This work was followed by pumping the accumulated water from the trenches, and was completed in the spring of 1981.

In December 1980, Nuclear Fuel Services' lease with the New York State Energy Authority expired. The State Departments of Environmental Conservation and Labor, regulators of the disposal area, required Nuclear Fuel Services to continue to maintain the site beyond the lease expiration date until the facility licenses were transferred to the Energy Authority. The Energy Authority assumed possession of the disposal facility and responsibility for surveillance and maintenance of the site in the spring of 1983. 
Monitoring by the Energy Authority indicated that, in spite of the trench cap rehabilitation program, water continued to infiltrate into the disposal trenches. Since the last pumping in 1981, the trench water levels in most of the trenches had increased; the most significant increase occurred in Trench 14. A review of trench water level and onsite precipitation data indicated a strong correlation between rainfall and increased water levels in the trench. Trench cover failure was initially suspected, but inspections revealed no identifiable flaws. It was noted, however, that during the spring and summer of 1986, tirere was an unusual amount of precipitation during frequent severe thunderstorms and, at times, standing water was observed in the field west of Trench 14. Further investigations revealed the presence of a permeable sand and gravel zone within the generally impervious glacial till. This permeable zone was oriented such that it appeared to intersect the trench and came very close to ground surface about $90 \mathrm{ft}$ from the trench. The Energy Authority concluded that the sand and gravel zone had the potential to conduct water into the trench, particularly when the ground surface was flooded.

Since it appeared that the water level in the trench was at or slightly below the intersect of the sand and gravel zone, the Energy Authority requested and was granted permission to lower the water level in Trench 14 at least one foot below the intersect by transferring the water into two adjacent trenches. This transfer was performed in early February 1987. In mid-February, a subsurface concrete wall was installed immediately west of the trench. This wall was to provide additional protection against water entering the trench, and to create a surface against which the planned extensive excavation work in the sand and gravel zone could be conducted.

In the summer of 1987 , the Energy Authority completed the remainder of the remedial action project. The effort consisted of removing the entire sand and gravel zone west of the concrete wall, replacing it with compacted clay from a nearby borrow area, grading the affected area for more effective drainage, and establishing a vegetation cover. No contamination was found in the sand and gravel zone. 


\section{Facility Status}

Between 1983 and 1986, the Energy Authority and the U.S. Department of Energy sponsored a project to evaluate options for long-term management of the shutdown commercial disposal facility. The objective was to place the facility in a condition which would eventually require only passive custodial care and monitoring to protect the public health and safety and the environment. Of the seven trench stabilization methods considered, the natural stabilization alternati.. as selected. Natural stabilization would allow the trenches to settie ariu tabilize naturally for however long was necessary, perhaps 25 to 50 years. Once the site stabilized, a structural engineered cap would be installed. This plan essentially assumed the continuation of the interim site management program pending site stabilization.

However, the Energy Authority has since decided to close the entire Nuclear Service Center when the West Valley Demonstration Project (WVDP) is completed, and has entered into a joint agreement with the Department of Energy to prepare an Environmental Impact Statement for completion of the WVDP and closure of the Center. Currently site characterization data needed for the EIS are being obtained. An independent contractor will be selected by the end of 1990 to prepare the Environmental Impact Statement. The final EIS is scheduled to be issued in late 1994 .

The West Valley commercial disposal site continues to be maintained in a shutdown status, with the necessary monitoring being conducted by the Energy Authority. In mid-1990, the water level in Trench 14 reached the February 1987 pre-transfer level. The Energy Authority is currently in the process of obtaining the necessary permits from the State Department of Environmental Conservation to allow removal and treatment of the infiltrate in Trench 14 . 


\section{Richland, Washington}

The Richland commercial low-level waste disposal site is located on the central plateau of the Hanford Reservation, about 23 miles northwest of Richland, Washington, in the southeastern part of the State. The site consists of 100 acres of land leased by US Ecology, Inc., from a 1000-acre tract on the Hanford Reservation that is leased by the State of Washington from the Department of Energy (DOE).

\section{Site Description}

The Hanford Reservation is located in the Pasco Basin on the semiarid alluvial plain of the Columbia River. The disposal site is situated on glacier-fed river sediments of the ancestral Columbia River that consist of sand, silt, and gravel in various combinations (Figure 8 ). These deposits are up to about $200 \mathrm{ft}$ in depth and overlay the Reingold Formation, which is a layer of sedimentary material up to $1200 \mathrm{ft}$ thick. Below this formation, the bedrock consists of Yakima Basalt. The land is generally flat with intermittent dunes, except where grading has occurred. The surface dunes consist. of fine silt and sand and are subject to migration in areas where the fragile vegetative cover has been destroyed. The depth of the water table in the region of the disposal site ranges from 195 to $350 \mathrm{ft}$, with the bottom of this unconfined aquifer being coincidental with the lowest layers of the Reingold Formation.

The Columbia River flows through the reservation about 6 miles from the commercial waste disposal site. There are no surface-water bodies on or near the disposal site. Two ephemeral streams and a small natural pond are located on the surrounding reservation.

The Pasco Basin is characterized by a semiarid climate, with an average annual precipitation of about 6.3 inches and an annual potential evaporation rate of 55 inches. 
The Richland commercial low-level radioactive waste disposal site is unique among comparable sites in that it is the only one located on Federal 1and. The Hanford Reservation includes a number of DOE nuclear research facilities, including reactors, chemical processing plants, laboratories, and supporting facilities. The commercial low-level waste disposal site is essentially bounded on the east and west sides by two DOE radioactive waste disposal areas that have been used for the disposal of waste since 1944 and are still in active use.

The site currently consists of 14 parallel land disposal trenches that vary dimensionally from 300 to $840 \mathrm{ft}$ in length, 25 to $140 \mathrm{ft}$ in width, and 20 to $45 \mathrm{ft}$ in depth (Figure 9). The site also hosts four $30-\mathrm{ft}$-deep caissons located between Trenches 3 and 4 and three underground steel tanks ranging in size from 1000 to 20,000 gallons (originally there were five tanks; two were removed in the mid-1980s and the remaining three tanks are no longer in use).

\section{Operating History}

The disposal site was licensed and opened as a commercial venture in September 1965 and, except for a brief period in 1979, has operated since that time. The first licensed operator of the site was California Nuclear, Inc. In March 1968, the assets of the company were transferred to the Nuclear Engineering Company (NECO), which in 1981 changed its name to US Ecology, Inc.

Washington has been an Agreement State since December 1966. Since that time, the State has assumed responsibility for licensing the possession and disposal of source and byproduct material, while the NRC retains responsibility for licensing the possession and disposal of special nuclear material exceeding certain limits.

Low-level radioactive waste is disposed of primarily by shallow-land burial. The disposal trenches are opened, as needed, and used in an alternating sequence to allow room for the stockpiling of excavated soil and to facilitate trench access. The waste containers are placed in the trench, with a minimum distance of $8 \mathrm{ft}$ left between the top of the waste and the 


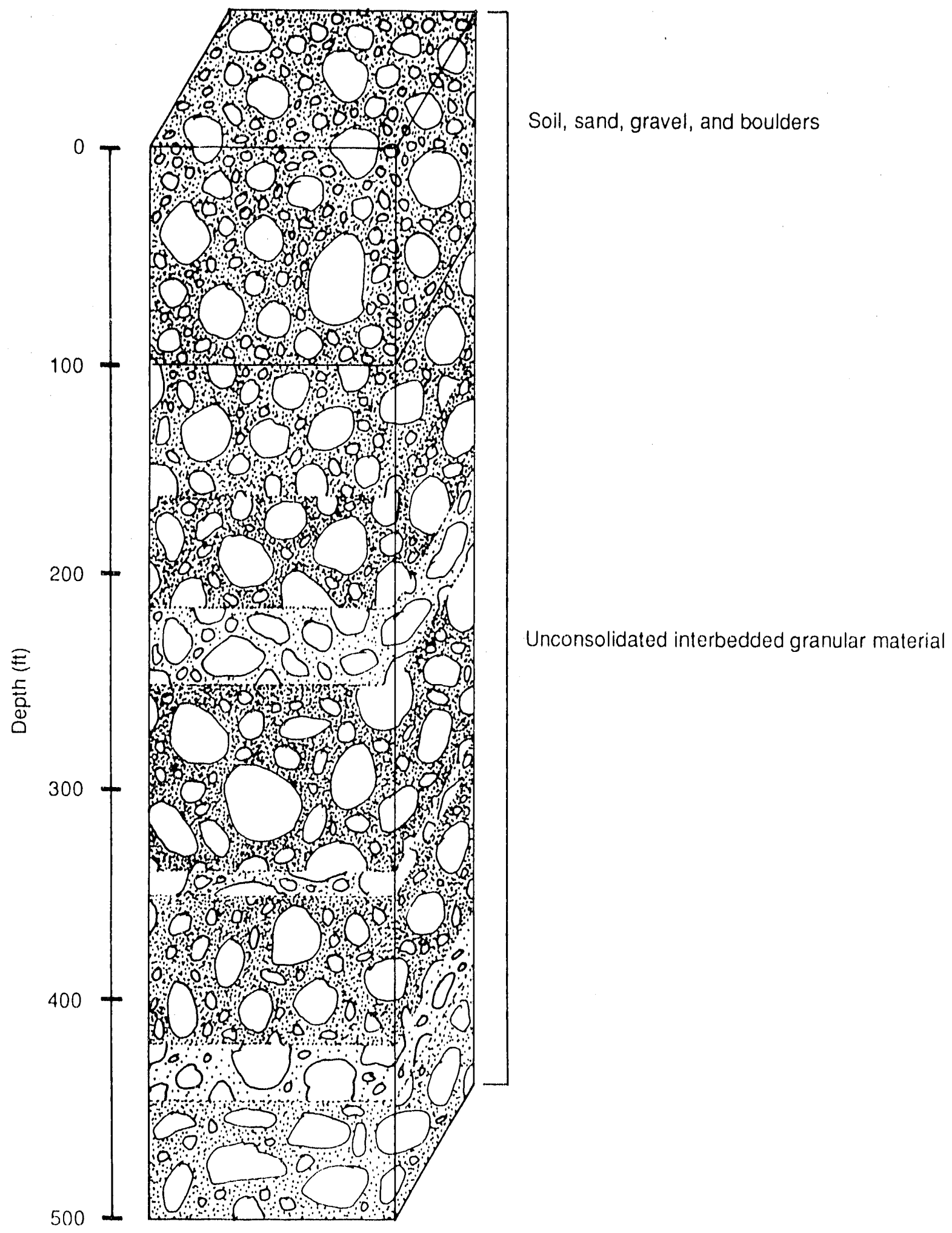

figure 8. Richland, Washington, disposal facility site geology. 


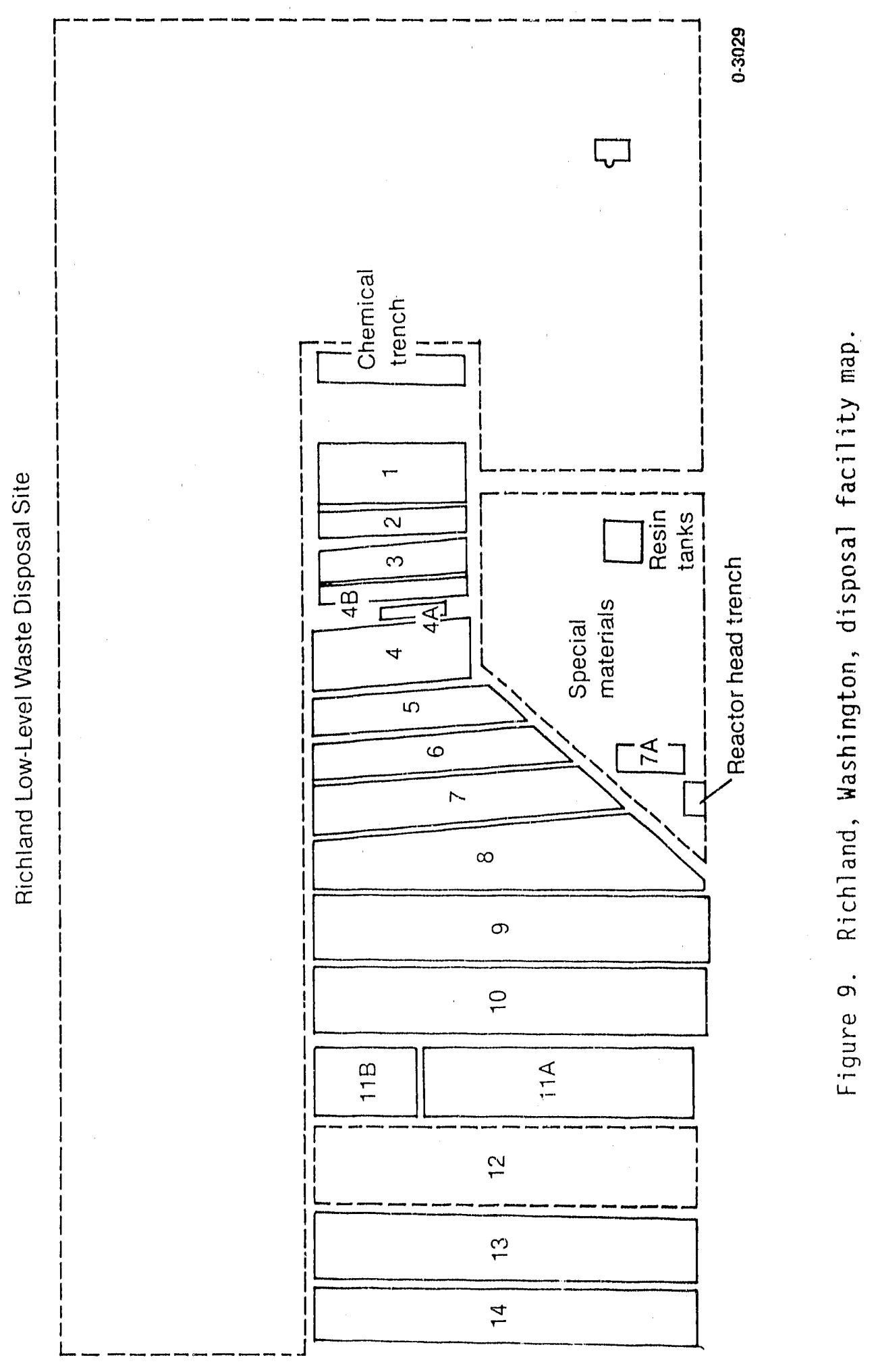


original ground surface. The trench is backfilled with the previousiy excavated soil. After the trench is filled to the original level, a soil cover is formed into a mound which is at least $5 \mathrm{ft}$ thick along the trench centerline and $3 \mathrm{ft}$ thick near the trench edge. A 6 -inch layer of gravel and cobble is then placed on the mound to protect the cover soil against wind erosion and burrowing animal intrusion. The boundaries of the disposai trenches are surveyed and referenced to a concrete post benchmark, which is, in turn, keyed to the site records.

Disposal practices other than the conventional disposal in shallow trenches have been used at the Richland facility, including the use of caissons and resin tanks. The caissons are used for the disposal of waste with high surface radiation readings. The caissons consist of four wells, $30 \mathrm{ft}$ deep and lined with steel pipe, which are closed off at both ends with concrete.

Five underground steel tanks, ranging in size from 1000 to 20,000 gallons, were installed in the late 1960s for evaporating and solidifying liquid resin wastes. Their use was discontinued in the early 1970s. The tanks and associated wastes were left in place with little attention until early 1985, when leaks in the tanks and contamination of adjacent soils were discovered. US Ecology, Inc. removed the liquid waste from the tanks and subsequently removed and disposed of two of the five tanks. The remaining three tanks were filled with concrete. U.S. Ecology then placed plastic over the tank area to prevent the contaminated soil from becoming airborne.

During the period between the beginning of waste disposal operations in 1965 and the end of 1989, over 11.2 million $\mathrm{ft}^{3}$ of waste, containing about 34 million curies of byproduct material, were disposed of at the Richland site (Table 1). In addition, over 13.3 million 16 of source material and about $343 \mathrm{lb}$ of special nuclear material were disposed of in that period.

Except for the underground tanks, the Richland low-level waste disposal facility has experienced no problems related to site operations or waste 
containment. However, as with the Barnwell and Beatty sites, routine inspections of incoming waste in 1979 lead to the discovery of violations of transportation and packaging regulations. Consequently, the disposal site was shut down by the Governor of Washington during October and November of 1979 while problems with incoming waste shipments were resolved. The site was reopened only after assurance was given by the Federal Government that action would be taken to enforce shipper compliance with transportation regulations, and after a compliance certification plan was adopted by the governors of the three States with operating commercial disposal facilities.

Despite these actions, there was continuing public concern over the safety aspects of waste transportation. There was also a growing opinion that the State of Washington should not be a repository for radioactive wastes generated in other regions of the country. This culminated in the $1980 \mathrm{~s}$ in a significant referendum decision by the voters of the state of Washington to close the site to all nonmedical and out-of-state waste shipments after July 1, 1983. However, in response to court challenges, the referendum was declared unconstitutional. This ruling was upheld in the appellate court.

\section{Facility Status}

Washington became a member of the Northwest Interstate Compact in 1985. As one of the three sited states, Washington is obligated to allow the Richland facility to dispose of wastes generated outside the compact through 1992, as long as the States in which the generators are located continue to meet the milestones prescribed in the LLRWPAA of 1985. The LLRWPAA of 1985, however, limits the amount of waste the Richland facility is required to accept to 9.8 million $\mathrm{ft}^{3}$ during the seven year period (as based on an average annual volume of 1.4 million $\mathrm{ft}^{3}$ of low-level waste).

Disposal costs have increased considerably in recent years, with the 1988 basic disposal rate being $\$ 29.60 / \mathrm{ft}^{3}$. Of this basic fee, $\$ 1.75 / \mathrm{ft}^{3}$ is deposited in a site closure account. In addition, a site surveillance fee of $4 \%$ is charged. The State of Washington also imposes a $15 \%$ Business and occupation tax on the facility operator. 
Site characteristics, such as the depth to the water table, climatic conditions, and a soil media with high absorptive capacity, together with engineered barriers such as the deep layer of soil placed over the waste, have resulted in favorable conditions for low-level waste disposal at the Richland facility. Environmental monitoring programs are conducted by DOE, the state of Washington, and US Ecology, Inc, to evaluate radioactivity concentrations along potential exposure pathways. The program includes analys is of groundwater in onsite wells, offsite surface water, air, soil, and vegetation. To date, the monitoring program has confirmed that the waste is contained within the disposal trenches and that no migration has occurred.

\section{The Future}

In 1984, based on approximate calculations, it was estimated that the Richland site may be exhausted as a low-level waste disposal facility in roughly 33 years, but that waste disposal could continue for as long as 66 years if conservative trench methods and deeper excavation were used. Washington has agreed to serve as the Host State for the Northwest Compact for an indefinite period, providing certain assurances are met by the other member States.

For future disposal, US Ecology, Inc., has proposed a "Comprehensive Facility Utilization Plan" to develop the remainder of their 100 -acre sublease into one large, continuously excavated and operated deep trench (Trench 15). According to the facility's plan, Trench 15 would be used exclusively for the disposal of Class A waste. Two conventional trenches (Trenches 12 and 14) would be used for the disposal of Class $B$ and Class $C$ waste, solidified or absorbed oils and solidified or absorbed chelating agents, as well as some Class $A$ waste. The plan also indicates that a "Special Projects Waste Area" (waste that requires special handling beyond what can be performed in Trenches 12, 14, and 15) would be developed east of Trenches 5 through 8. Approval of this plan has not been granted due to many unanswered questions relating to design, construction, and operation of Trench 15. 
The Washington State Department of Ecology has prepared a two-phase report on the closure and perpetual care and maintenance of the Richland disposal facility. The report recommends the use of a multiple-layer cover consisting, from bottom to top, of a cover foundation, a hydraulic barrier, a biotic barrier, a capillary barrier, a gravel-top dressing, and a vegetative surface layer as the closure design. The report also recommends that inspection and monitoring activities be conducted quarterly during the first 25 years of the perpetual care and maintenance period, semiannually for the second 25 years, and annually through the duration of the institutional control period. 


\section{Sheffield, 111 inots}

In October of 1966, the Illinois Department of Public Health signed a lease with California Nuclear, Inc. permitting the establishment of the Sheffield disposal site. The Sheffield low-level radioactive waste disposal site is located about 5 miles southwest of Sheffield, Illinois. Sheffield is about 140 miles west-southwest of Chicago, and about 45 miles east-southeast of Moline. The disposal site is on a 190-acre tract of 1 and adjacent to two hazardous waste disposal areas. The hazardous waste disposal areas are located to the north and northwest of the site. The Sheffield disposal site, opened in 1968, was first operated by California Nuclear, Inc., and later by the Nuclear Engineering Company Inc. (NECO), now US Ecology, Inc. Disposal operations ceased in 1978 when the site operator experienced lengthy delays during the license renewal process.

\section{Site Description}

The Sheffield $1 \mathrm{Jw}$-level radioactive waste disposal site is located on rolling glaciated terrain. The ground in which the disposal trenches were placed consists of wind-blown silt, pebbly clay, water-deposited sand and gravel, lake deposits of silt and clay, and silty, sandy stream sediments (Figure 10). The site is underlain by both shallow and deep aquifers. The bedrock underneath the site is approximately $450 \mathrm{ft}$ thick and provides a relatively impermeable barrier between the two aquifers. A pebbly sand unit extending across the middle of the site, and continuing offsite to the northeast, lies under approximately two-thirds of the site and forms the most permeable unit at the site. This pebbly sand unit serves as an underground drain, carrying the bulk of the groundwater from the site.

The site is in the headwater tributaries of Lawson Creek, which is 1 mile east of the site at its nearest point. Three small intermittent streams drain the Sheffield site. Two streams drain the southern portion of the site, and the third drains the northern portion of the site. A small lake is located directly north of the site. The climate is humid with a mean 
annual precipitation of about 35 inches. This exceeds evapotranspiration by about $10 \%$.

The waste is buried in 21 separate trenches (Figure 11). A typical trench is $500 \mathrm{ft}$ long, 50 to $60 \mathrm{ft}$ wide, and 20 to $25 \mathrm{ft}$ deep. A minimum of $10 \mathrm{ft}$ separates the trenches at the surface.

\section{Operating History}

Since the Sheffield site was established, regulatory responsibilities for site activities have been shared by the State of Illinois and the U.S. Atomic Energy Commission, now the NRC. The NRC regulates the possession and disposal of byproduct, source, and special nuclear material at the site. The Department of Public Health owns the 20 acres of land used for disposal and regulates possession and disposal of naturally occurring and accelerator-produced materials. The original California Nuclear, Inc. licenses were transferred to Nuclear Engineering Company, Inc. (NECO), now U.S. Ecology, Inc., in March 1968. U.S. Ecology, Inc. remains the licensee for the site.

The site was used for disposal of radioactive waste from August 1967 through April 1978. During that time, over 3 million $\mathrm{ft}^{3}$ of waste material containing about 60,000 curies of byproduct material, 126 ib of special nuclear material, and about 1 million $1 \mathrm{~b}$ of source material, were buried within the original 20 -acre tract (Table 1).

\section{Basis for Facility Closure}

The growth of the nuclear power industry in the early 1970s rapidly increased the demand for low-level radioactive waste disposal space. The annual volume of waste received at Sheffield increased from about $9000 \mathrm{ft}^{3}$ in 1970, to about $57,000 \mathrm{ft}^{3}$ in 1977 , the year before the site was closed. In 1975, the Nuclear Engineering Company, Inc. requested the NRC issue a modification to its license that would permit compacted-fill trenches and, 


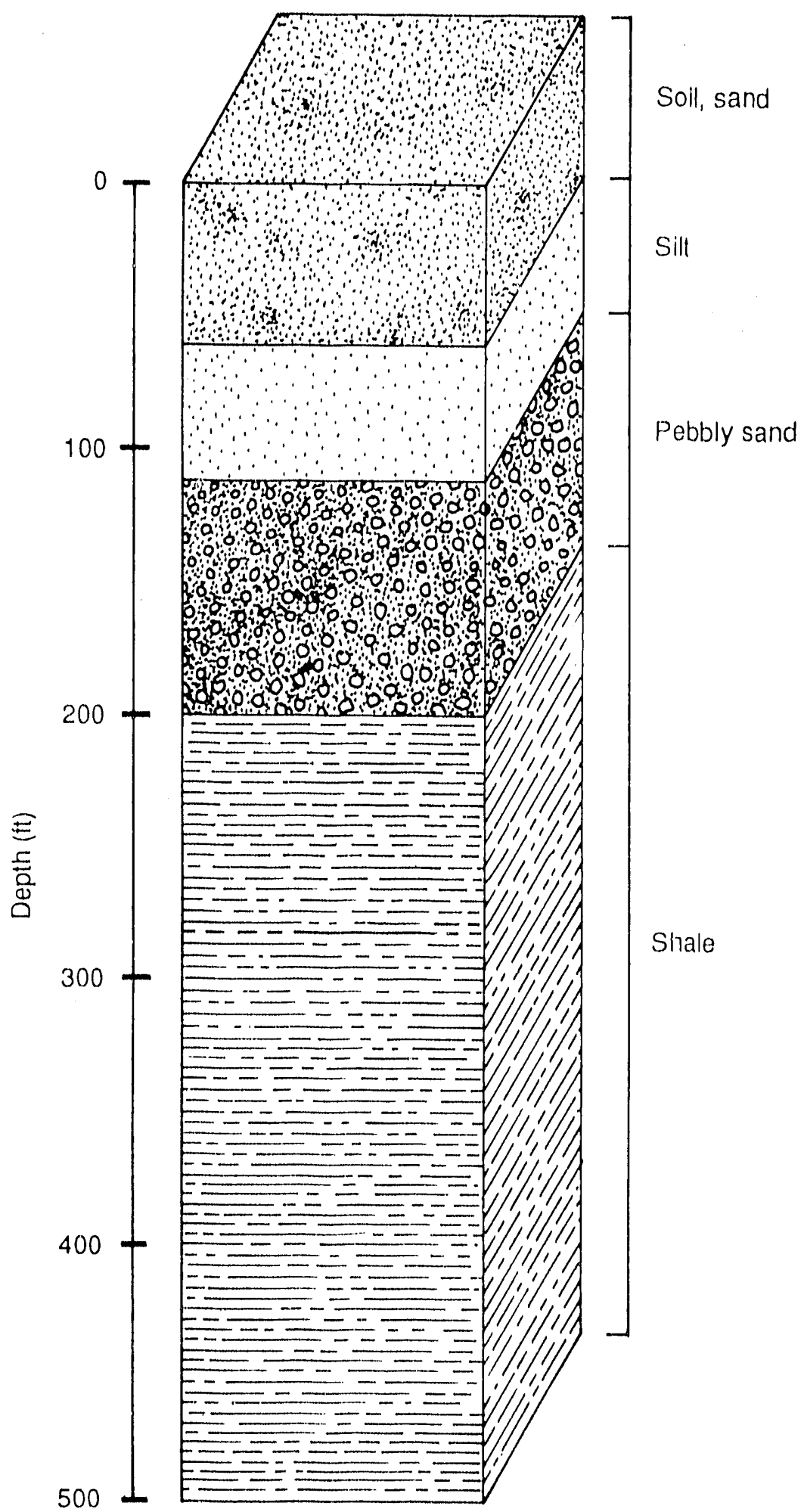

- Bivis

ligure 10. Sheffield, Illinois, disposal facility site geology. 


\section{Sheffleld Low-Level Waste Disposal Site}

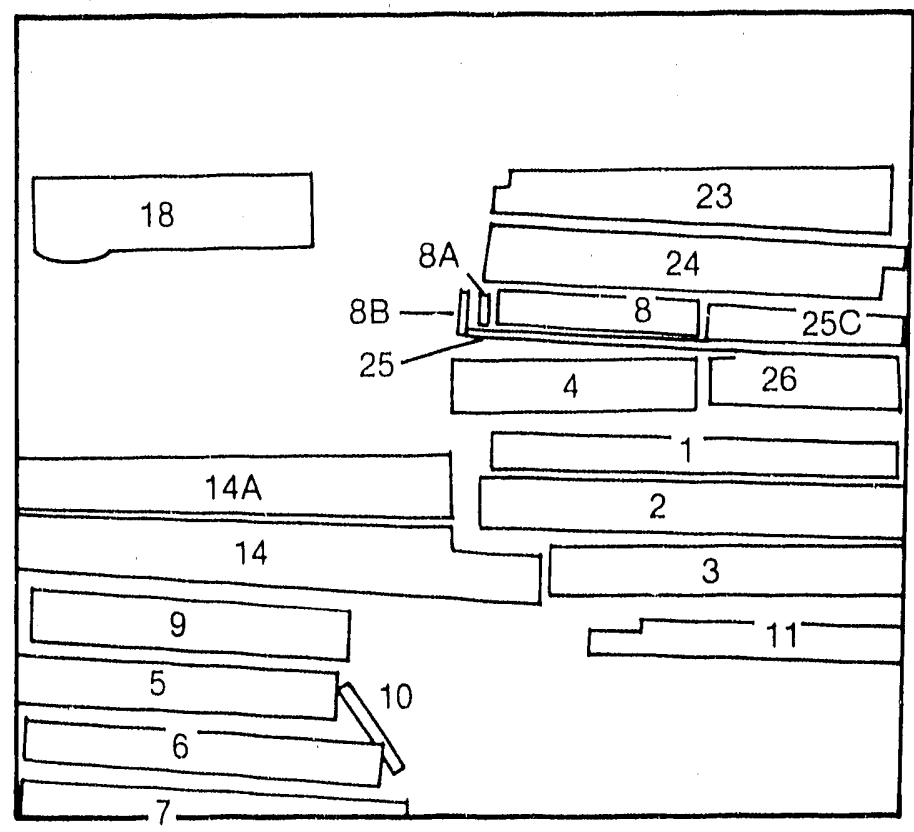

This map is an artist's rendering from inexact input and is therefore not accurate as to measurements and distances.

0.3033

Figure 11. Sheffield, Illinois disposal facility map. 
thereby, increase the capacity and lifetime of the original 20 -acre tract. The NRC requested that NECO supply additional information and also prepare an environmental report. In December 1975, the NRC authorized construction $C_{i}$ the new trenches but withheld approval to bury waste in these trenches until NECO submitted the requested information. About one year later, NECO submitted the environmental report and also requested expansion of the site as part of its application for license renewal. In August 1977, while the renewal-and-expansion application was being reviewed by the NRC, NECO requested that its license be amended to permit the construction of a new trench, Trench 15, in the originally licensed 20 -acre tract.

The original description of the site geology was based on information gained from a total of eight borings. Based on the information obtained from these borings both the applicant and the United States Geological Survey (USGS) concluded that the site was suitable for disposal of low-level radioactive waste. These early investigations also led to some conclusions on groundwater movement at the site. Based on the available information, the groundwater velocity was estimated to be between 3.5 and $7.0 \mathrm{ft}$ per year. On review, the USGS increased this estimate to between 10 and $20 \mathrm{ft}$ per year. siating that the velocity was dependent largely on the assumed geologic conditions at the site. In 1976, the USGS initiated a five-year study to further examine the site-specific geology and hydrogeology.

In December of 1977. tritium was found in samples taken from monitoring wells constructed by the USGS in the southeast corner of the site. It appeared that the tritium was migrating from Trench 11 and that the rate of groundwater movement from this trench significantly exceeded the original estimates. To further explore the site hydrogeclogy, the USGS performed a horizontal boring in the southeast corner of the site between December 1978 and March 1979. The information obtained from this boring indicated that the presence of sand and other coarse-grained deposits were far more extensive than discovered by the original site investigation.

In March 1978, the NRC ruled that Trench 15 could not be used for waste disposal. With the expansion application pending and no space in other 
trenches, the NRC ruling on Trench 15 led to a de facto closure of the site. In April 1978, NECO withdrew its application for Trench 15 and ceased disposal of radioactive materials.

\section{Post-Closure History}

In the late 1970s and early 1980s, the USGS installed additional monitoring wells at the north and east boundaries of the site because the general hydrogeolgic studies indicated groundwater movement to this area. In November 1981, tritium was detected in one of these wells. This was significant because it marked the first time that tritium had been detected beyond the original site boundary. Additional wells installed to the northeast of the site confirmed tritium movement in a narrow pathway to the northeast. The pathway for this radionuclide migration was believed to be intrusion of water into the disposal trenches, leaching of contamination from the waste, followed by leachate movement offsite via the permeable sand deposits.

Since the initiating event for the radionuclide migration was water intrusion, water management became an integrai part of site maintenance. Trench covers were graded to enhance precipitation runoff into drainage ditches, and water that did infiltrate the trenches was collected in sumps located in each trench and removed.

\section{Facility Status}

In March 1978, US Ecology, Inc. attemnted to terminate its license and iease with the state of Illinois. The State responded by filing suit against the company, saying that the company could not sever its contractual relationship with the State. The State sought a $\$ 97$ million judgment against the company in a dispute over who was responsible for maintenance of the site. In May 1988, US Ecology, Inc. and the State of 111 inois entered a settlement agreement that provided a plan for the closure, care, and maintenance of the low-level radioactive waste disposal site. The agreement was submitted to the Illinnis Circuit Court of Rureau county and the lawsuit. was dismissed with 
prejudice. Under the terms of the agreement, US Ecology, Inc. Was required to: (a) establish a long-term maintenance fund of $\$ 2.5 \mathrm{million}$, (b) establish a $\$ 1.65$ million escrow account conditioned on completing the terms of the settlement agreement, (c) complete specified physical improvements to the site, (d) start a chemical and radiological monitoring program, and (e) maintain the site for 10 years, after which site, buildings, and equipment are to be turned over to the State.

In September 1989, US Ecology, Inc. completed the construction of a new clay cap over the entire site, an improvement specified in the settlement agreement. The cap, designed to reduce water infiltration, consists of $4.5 \mathrm{ft}$ of compacted clay, covered with six inches of vegetated topsoil. The company is in the process of implementing a revised environmental monitoring program that includes testing ground and surface water, soil, fish, and vegetation for radioactive and hazardous chemical contamination. US Ecology, Inc. is also in the process of installing new monitoring wells at the site.

US Ecology, Inc. and the State are now beginning the 10-year period of monitoring and maintenance. At the end of this period and upon completion of all settlement terms, the State of Illinois will assume ownership of the site and US Ecology, Inc. will be released from further responsibilities. 


\section{Barnwell, South Carolina}

The Barnwell low-level radioactive waste disposal facility was originally licensed for above-ground storage of radioactive waste in November 1969. The 1icense was amended in April 1971 to permit Chem-Nuclear Systems, Inc. (CNSI), the site operator, to bury low-level radioactive waste, and waste disposal was subsequently initiated. Since then, the Barnwell site has operated continuously. The Barnwell site is located near the eastern boundary of the DOE's Savannah River Plant in the southwestern part of South Carolina. The disposal site consists of 300 acres of land located about 5 miles west of the town of Barnwel1, South Carolina, and on the edge of the small community of Snelling.

\section{Site Description}

The site is located on part of the Coastal Plain geologic province, which is characterized by flat, largely unconsolidated sediment layers (Figure 12). Onsite soil consists of a layer of topsoil containing sand, clay, and organic material, overlying a layer of fine and silty sands

( 2 to $7 \mathrm{ft}$ thick), followed by the sandy clay and dense clays (14 to $30 \mathrm{ft}$ thick) of the Hawthorne Formation. A regional groundwater table lies within the Hawthorne Formation at depths that range from 30 to $60 \mathrm{ft}$. The principal source of potable water in the area is from the underlying Tuscaloosa Formation at depths in excess of $350 \mathrm{ft}$.

The nearest surface water to the site is Lower Three Runs Creek, which is about 3 miles away. This creek, a tributary of the Savannah River, drains the major portion of the site and flows into the river about 70 miles downstream. However, because of the gentle slope of the topography and the absorptive nature of the sand cover, surface water runoff occurs only after unusually heavy rainfall.

The climate at the site is mild and humid, with a mean annual precipitation of 47 inches (ranging from 29 to 73 inches). Regionally, about 
15 inches of the annual average rainfall infiltrates to the water table. The water table aquifer flows at a rate of approximately $7 \mathrm{ft}$ per year.

The site currently consists of 73 standard trenches and seven sli.t trenches (Figure 13). The standard trenches vary dimensionally from the initial four trenches, each of which is $200 \mathrm{ft}$ long by $50 \mathrm{ft}$ wide by $15 \mathrm{ft}$ deep, to the current typical unit which is $1000 \mathrm{ft}$ long by $100 \mathrm{ft}$ wide by $21 \mathrm{ft}$ deep. The slit trenches, which get their name from their dimensions, are 4 feet wide by 500 feet long and approximately 22 feet deep.

\section{Operating History}

South Carolina became an NRC Agreement State in 1969. As an Agreement State, South Carolina licenses the operation of the low-level waste disposal facility, through the State Department of Health and Environmental Control, under authority delegated by the NRC. The operating license covers the possession and disposal of source and byproduct material, while a separate NRC license covers the possession and disposal of special nuclear material.

Low-level radioactive waste is disposed of primarily by shallow-land disposal. The disposal trenches are constructed to facilitate the collection and removal of leachate, with a floor sloping to one side, where a French drain runs the length of the trench and is sloped about $0.3 \%$. Water collection sumps are placed at $500-\mathrm{ft}$ intervals along the French drain, and standpipes, for removal of leachate, are located in the sumps and at intervals along the trench. A layer of sand (2 to $3 \mathrm{ft}$ thick) is placed on the bottom of each trench to provide an even foundation for waste packages and to ensure that any water entering the trench will drain from the bottom layers of waste and into the French drain for collection. Layers of sand in the trench walls are replaced with compacted clay to reduce lateral infiltration of moisture into the trenches from the surrounding soil. 


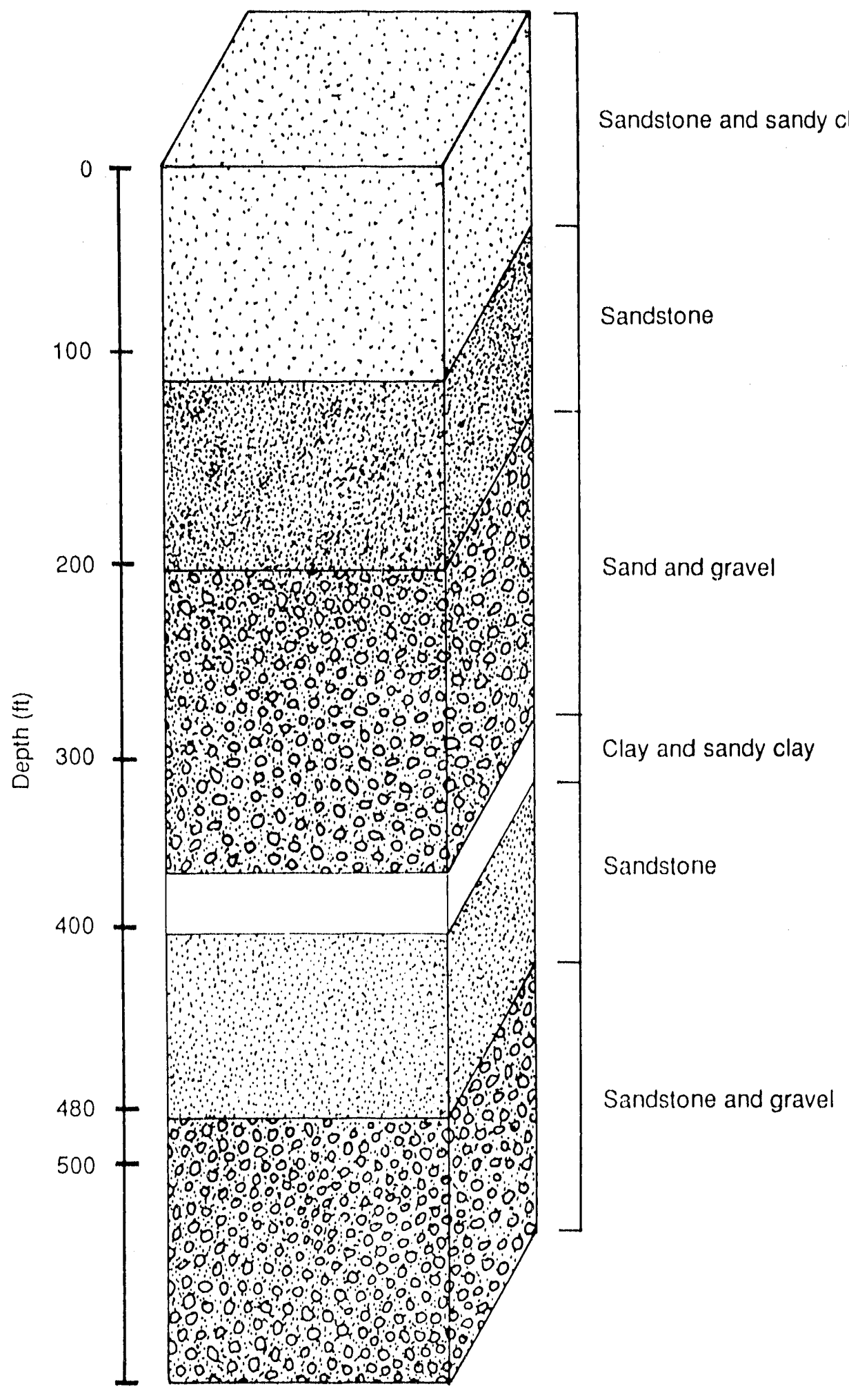

Simplified geology for the Barnwell, South Carolina low-level waste disposal site.

0.3037

iqure 12. Barnwell. South Carolina, disposal facility site geology. 


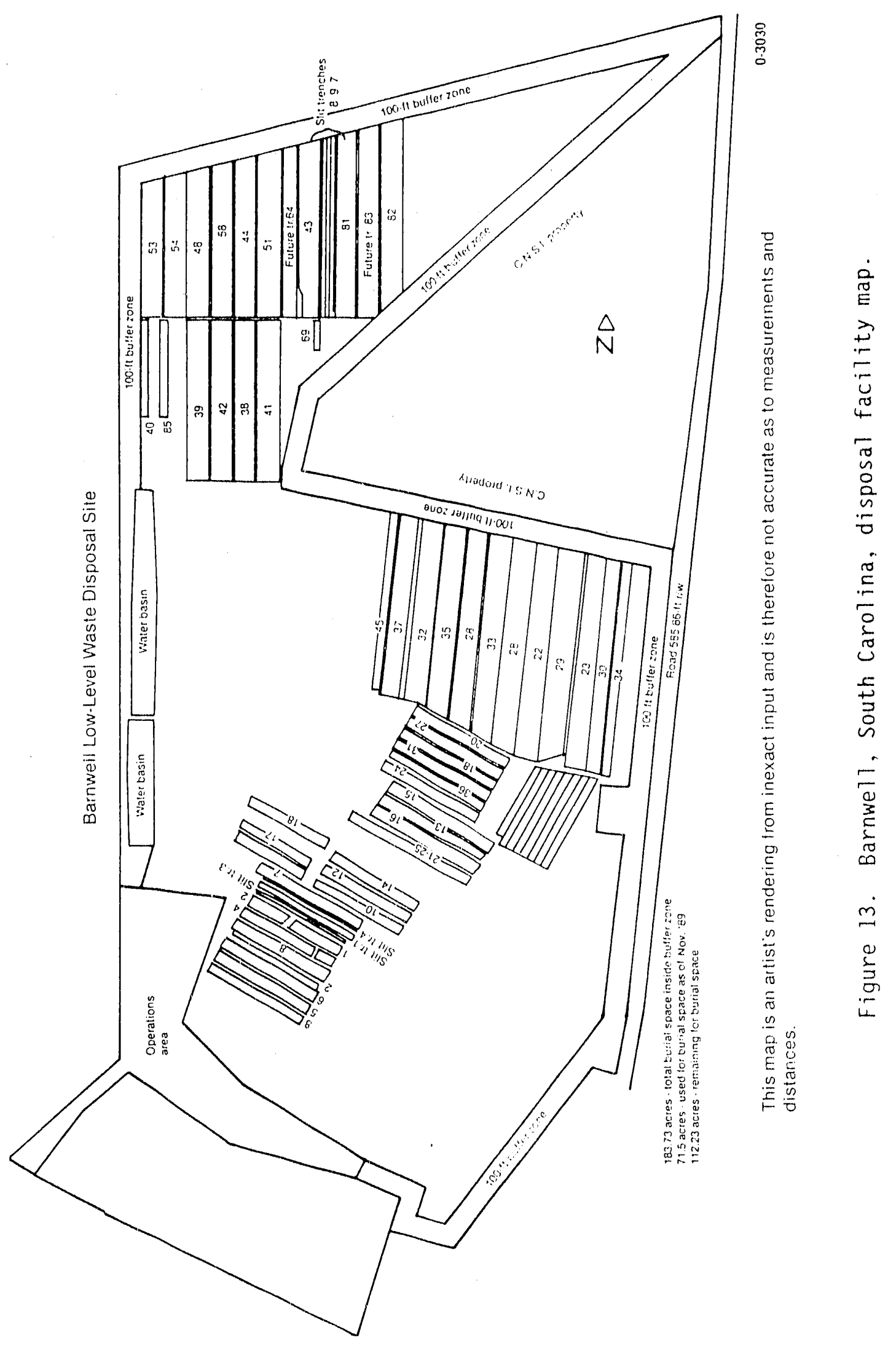


Waste is typically placed in the trench, starting at the high end of the trench floor, by stacking boxes and components and then filling the intervening spaces with drums and small packages. Upon completion of waste emplacement, trenches are backfilled with sand to fill remaining voids between packages and provide drainage paths away from the waste for any rainwater infiltrate. A layer of soil with a minimum thickness of $3 \mathrm{ft}$ is then placed over the trench, followed by a layer of compacted clay at least $2 \mathrm{ft}$ thick. Topsoil, 6 to 18 inches deep, is applied and a cover crop planted. The completed trench is located with permanent granite markers at the ends and at the four trench corners, which are keyed to the site records.

Waste with a high radioactive content is disposed of in slit trenches where the deep, narrow trench aids in minimizing exposure to workers during offloading operations. The trenches are excavated in $125 \mathrm{ft}$ segments to prevent cave-ins. Gravel is added to the trench floor in 1 to $3 \mathrm{ft}$ depths to provide rapid water drainage. Once waste is placed in the trench, clay is backfilled over the package to reduce radiation emission from the area. As on the standard trenches, a clay cap and concrete intruder barriers, are installed later.

From the beginning of disposal operations in 1971 through 1989, over 21.7 million $\mathrm{ft}^{3}$ of waste containing about 4.6 million curies of byproduct material were disposed of at the site (Table 1). In addition, almost 30 million lb of source material and about 5598 ib of special nuclear material were disposed of in that period.

The Barnwell low-level waste disposal facility has not had significant problems specifically related to either site operations or to onsite waste management. However, as with the Richland and Beatty sites, the Barnwell facility has discovered waste packaging and transportation violations. Unlike the Beatty and Richland facilities, the violations were not severe enough to close the Barnwell facility. When the volume of waste received at the site increased substantially, after closure of three of the other sites, the Governor of South Carolina instituted a program which began a two-year phasedown of the volume of waste accepted at the Barnwell site to 
1.2 million $\mathrm{ft}^{3} /$ year (almost a $50 \%$ reduction). In 1979 , the developing problems led to unified actions to tighten generator and transporter compliance procedures, as well as actions to upgrade waste-acceptance standards at the three sites. This resulted from imposing new license provisions and adopting administrative constraints.

\section{Facility Status}

South Carolina became a member of the Southeast Interstate Compact in 1985. As one of the three sited States, South Carolina is obligated to allow the Barnwel1 facility to dispose of wastes generated outside the compact through 1992, as long as the States in which the generators are located cont inue to meet prescribed milestories of the LLRWPAA of 1985. The LLRWPAA of 1985, however, limits the amount of waste Barnwell is required to accept to 8.4 million $\mathrm{ft}^{3}$ in the seven year period (as based on an average annual volume of 1.2 million $\mathrm{ft}^{3}$ of low-level radioactive waste).

Partly as a result of the limits on allowable volume and the additional operating constraints imposed, unit disposal costs have increased considerably in recent years, the 1988 basic rate being $\$ 36.87 / \mathrm{ft}^{3}$. There are additional incremental costs for decommissioning the site upon closure and for providing a perpetual care fund for the site. These charges were approximately $\$ 2.80 / \mathrm{ft}^{3}$ in 1988 and are transferred to the State. Additional charges include a $\$ 6 / \mathrm{ft}^{3}$ radioactive waste tax and a $\$ 40 / \mathrm{ft}^{3}$ surcharge on non-Southeast Compact waste. Barnwell County also imposes a $2.4 \%$ tax on all disposal fees.

The environment surrounding the facility is closely monitored. The Barnwe11 sitc operator, CNSI, monitors onsite and offsite wells quarterly for signs of radioactive contamination. In addition, periodic sampling of soil, plants, and animals are taken and the air is monitored on a continuous basis. A comprehensive study of the Barnwell facility, conducted by the United States Gcological Survey (USGS), indicates that some migration of radionuclides from the buried waste has occurred out to a distance of $10 \mathrm{ft}$ from some of the older disposal trenches. Remedial actions which consisted of re-capping these 
trenches has slowed the migration and a rigorous health physics and contamination monitoring program is being maintained. The contamination control program is governed by levels specified by the license conditions and is subject to inspection by State personnel. There have been no problems on the site related to excessive site-surface contamination or to the spread of contamination through waste handling.

\section{The Future}

Under terms of the Southeastern Regional Compact, South Carolina will cease to be the regional disposal facility by December 31, 1992. The Southeast Compact Commission has designated North Carolina as the next Host State. The Governor of South Carolina formally notified the Southeast Compact Commission in November 1988 that the Barnwell facility will close on December 31, 1992, in compliance with a provision of the compact requiring notification four years in advance of closing a regional facility.

Upon closure of the Barnwell facility, the State of South Carolina will oversee the decommissioning and stabilization of the site. The land will be stabilized according to a pre-developed plan drafted by CNSI and approved by the state. The plan will incorporate schedules for closure, estimated costs for passive maintenance of buffers and trench caps, and an environmental monitoring plan. The final draft will be submitted no later than 1 year before closure of the site.

Upon closing of the site, all equipment will either be decontaminated or disposed of, and the area will be graded to drain water away from the trenches and to minimize erosion of the trench covers. A passive site security system will remain in effect, and will require minimum maintenance.

A Decommissioning and Perpetual Care Fund has been established for the long-term maintenance of the site. This fund will be used to provide equipment necessary for environmental monitoring and any maintenance that may be necessary to trenches, security systems, and equipment. Perpetual care and 
maintenance of the site will be performed by a designated state agency for a period of at least 100 years. 


\section{GLOSSARY}

Active

maintenance

Activity

Adsorption

Agreement

State

Aquifer

Aquitard

Byproduct material

Curie

Decay

(radioactive)

Desiccation

Dismissed with

prejudice

Erosion

Evapotranspiration
Any significant remedial activity performed during the period of institutional control to maintain the performance objectives of the disposal facility.

The rate at which a radioactive material emits radiation.

Adhesion of molecules to the surface of solid bodies with which they are in contact.

A state which has entered into an agreement with the Nuclear Regulatory Commission to license and regulate its own commercial low-level waste disposal facilities and low-level waste management activities.

An underground bed or stratum of earth, grave1, or porous stone that contains water in recoverable quantities.

An underground bed or stratum of impermeable material, that acts as a barrier to water movemerit.

Radioactive materials obtained during the production or use of source material; it includes fission products and other radionuclides produced in nuclear reactors.

A unit of radioactivity defined as the amount of radioactive material having an activity of 37 billion disintegrations per second.

Millicurie: One-thousandth of a curie.

Microcurie: One-millionth of a curie.

Nanocurie: One-billionth of a curie.

The decrease with time of the amount of radioactive material present, as a result of the disintegration process leading to the formation of stable, nonradioactive elements.

The act of removing moisture from an object. Desiccative cracks are cracks in the ground caused by the drying action of the sun.

A legal term meaning that once the case is dismissed, the plaintiff is not allowed to bring suit against the defendant on the same charge.

The process by which soil and rock materials are carried away by the action of wind or water.

The total water loss from an area, being the sum of evaporation from the soil and transpiration from vegetation. 
French drain A gravel- or cobble-packed trench designed to collect and carry fluid along its entire length and to support a vertical load.

Glacial Sediments transported in, or deposited by, glaciers.

drift

Groundwater Subsurface water which is located within a zone of saturation.

Grout Various materials (such as a mixture of cement and water or chemicals that solidify) used for filling spaces.

Half-Life The amount of time it takes for any amount of a radioactive substance to decay to one half that amount. See Appendix A.

Host State A State which has, or is planning to have, a low-level radioactive waste disposal facility.

Hydrological Relating to the study of the water of the earth.

Institutional The period of time following closure of the disposal facility control during which the site custodial agent maintains control of the facility and monitors its performance. Institutional control is assumed to continue indefinitely, but in technical analysis, control of the site may be assumed to last for only 100 years after facility closure.

Ion-exchange Small resin beads used to remove radioactive particles from resins contaminated 1iquid.

Leachate

A solution obtained by the action of a percolating liquid dissolving the substance through which it moves.

Lithology The physical character of a rock determined by low-power magnification, e.g., mineral composition, grain size, and structure.

Migration The movement of radionuclides through air, soil, or water (radionuclide) See Appendix B.

Passive Routine care of a closed disposal facility which does not Custodial

Care

Permeable Having a texture that permits the movement of liquids or gases.

Plastic Being able to be molded into any shape and then retain that shape.

Precipitation water deposited on the earth in the form of hail, mist, rain, sleet, or snow. 
Radionuclide A radioactive species of an atom having a specific mass, atomic number, and nuclear energy state. Radionuclides are unstable and, therefore, radioactive.

Source Uranium, thorium, or a combination of both.

material

Special

nuclear

material

Plutonium, uranium-233, uranium-235, and any material artificially enriched by any of the foregoing.

Subsidence

The sinking of a large part of the earth's surface. In the context of this report, subsidence refers to the sinking of a disposal trenches' earthen cover caused by the decomposition and settling of the waste.

Surface water

Water contained on the surface of the earth, i.e., rivers and lakes.

Ti11 Unstratified glacial drift consisting of clay, sand, gravel, and boulders intermingled.

Transuranics Elements or radionuclides with an atomic rumber greater than that of uranium (i.e., greater than 92). Transuranic radionuclides normally have substantially longer half-lives than nontransuranic radionuclides, although this is not always the case. 


\section{READING LIST}

1. Brown, H., The Low-Level Waste Handbook: A User's Guide to the Low-Level Radioactive Waste Policy Amendments Act of 1985, November 1986. This guide provides a section-by-section discussion of the development of the Low-Level Radioactive Waste Policy Amendments Act of 1985. Write: The National Governor's Association. Hall of the States, 400 North Capitol St., Washington, D.C. 20001-1572.

2. Hurley, P.M., Living with Nuclear Radiation, 1982. This document discusses the risks associated with natural and human-made sources of radiation. Write: University of Michigan Press, Box 1104, 839 Greene St.. Ann Arbor, MI 48106.

3. League of Women Voters, The Nuclear Waste Primer: A Handbook for Citizens, 1985. This document provides an overview of problems associated with nuclear waste and its management. It describes how citizens can be involved in nuclear waste decisionmaking and identifies selected information sources. Write: Nick Lyons Books, 31 West 21 St., New York, NY 10010.

4. Murray, R.L., Understanding Radioactive Waste, 1989. This document provides simple and clear information on all aspects of radioactive wastes. Write: Battelle Press, 505 King Avenue, Columbus, $\mathrm{OH} 43201$.

5. National Conference of State Legislatures, Low-Level Radioactive Waste Management: An Update, October 1984. This document provides an overview of commercial low-level ratioactive waste disposal issues in the United States. Write: National conference of State Legislatures, Office of State Services, 1350 Seventeenth St., Suite 2100 , Denver, C0 80265.

6. Office of Technology Assessment, Partnerships Under Pressure: Managing Commercial Low-Level Radioactive Waste, November 1989. This document reports the status of state and regional compact progress towards developing low-level waste disposal facilities. Write: Superintendent of Documents, Government Printing Office, Washington, D.C. 20402-9325.

7. U.S. Department of Energy, "Answers to the Most Frequently Asked Questions About Low-Level Radioactive Waste Disposal in the United States." This pamphlet is a compilation of the most frequently asked questions about the disposal of low-level radioactive waste, and the Department of Energy's responses to these questions. Write: EG\&G Idaho. Natiunal Low-Level Waste Management Program, P.0. Box 1625, Idaho Falls, ID 834 i5-3960.

8. U.S. Department of Energy, "Low-Level Radioactive Waste Management Perspectives." This series of fact sheets provides a basic overview of radioactivity, low-level radioactive waste, and low-level radioactive waste management. Write: FG\&G Idaho, National Low-Level Waste Mailagement Program, P.0. Box 1625, Idaho Falls, ID 83415-3960. 
9 U.S. Department of Energy, 1989 Annual Report on Low-Level Radioactive Waste Management Progress. This report describes the activities and progress of the compacts and unaffiliated States in 1989 in developing new disposal sites for low-level radioaciive waste. In addition, the report summarizes information on low-level waste volumes shipped to the three currently operating disposal sites. Reports are also available for 1987 and 1988. Write: EG\&G Idaho, National Low-Level Waste Management Program, P.0. Box 1625, Idaho Falls, ID 83415-3960.

10. U.S. Geological Survey, Hydrogeological Factors in the Selection of Shallow Land Burial Sites for the Disposal of Low-Level Radioactive Waste, 1986. This document provides an overview of the impact of hydrogeology on the siting of a shallow-land low-level radioactive waste disposal sile. Write: Open-File Services Section, U.S. Geological Survey, Box 25425, Federal Center, Denver, C0 80225.

11. U.S. Nuclear Regulatory rommission, "Regulating the Disposal of Low-Level Radioactive Waste: A Guide to the Nuclear Regulatory Commission's 10 CFR Part 61," August 1989. This brochure provides: (a) an overview of 10 CFR Part 61 'requirements, (b) an overview of the history and background of low-level waste management, and (c) answers for some common questions about low-level waste management. Hrite: Division of Low-Level Waste Management and Decommissioning, Mailstop 5 E4, Office of Nuclear Material Safety and Safeguards, Washington, D.C. 20555. 


\section{BIBL IOGRAPHY}

A.T. Kearney, Inc., Closure and Perpetual Care and Maintenance of the Commercial Low-Level Radioactive Waste Disposal Facility on the Hanford Reservation, Phase One Report, September 1987.

A.T. Kearney, Inc., Closure and Perpetual Care and Maintenance of the Commercial Low-Level Radioactive Waste Disposal Facility on the Hanford Reservation, Phase Two Report, February 1989.

Anderson, D.B., Surveillance and Maintenance of the West Valley State Licensed Low-Level Radioactive Waste Disposal Area 1983-1987, 1988.

Brown, H., The Low-Level Waste Handbook: A User's Guide to the Low-Level Radioactive Waste Policy Amendments Act of 1985, November 1986.

Cahill, J.M., Hydrology of the Low-Level Radioactive Solid Waste Burial Site and Vicinity Near Barnwell, South Carolina, U.S. Geological Survey Jpen-File Report 82-863, 1982.

Case, M.J. and Otis, M.D., Guidel ines for Radiological Performance Assessment of DOE Low-Level Radioactive Waste Disposal Sites, July 1988.

Chem-Nuclear Systems, Inc., Economic Benefits of Chem-Nuclear's Low-Level Radioactive Waste Disposal Site to South Carolina, December 1986.

Dames \& Moore, Inc., Assessment of the Levels, Potential Origins, and Transpurt Routes of the Radioactivity Measured in the Vicinity of the Maxey Flats Low-Level Radioactive Waste Disposal Site, March 1977.

Dames \& Moore, Inc., Evaluation of Alternatives for the Future of Facilities. at the Western New York Nuclear Service Center, White Plains, New York, August 1978.

Dames \& Moore, Inc., Water and Sludge Management Alternatives for the Maxey Flats Low-Level Waste Disposal Site, March 1980.

Dragonette, K., Elackburn, J., and Cartwright, K., Interagency Task Force Report on the Proposed Decommissioning of the Sheffield Nuclear Waste Disposal Site, Nuclear Regulatory Conmission Informal Report, September 1979.

Envirosphere Co. Environmental Review of the Commercial Low-Level Kadioactive Waste Disposal Facility With in the U.S. Department of Energy's Hanford Siic, August 1985 .

Jacohs, R.G., Epler, J.S., and Rose, R.R., Identifiration of Technicdl Problems Encountered in the Shallow Land Burial of Low-Level Radioactive Wastes, ORNL/SUB-80-13619/1. March 1980. 
Haight, C.P., and Mills, H.D., "Remedial Action - Maxey Flats Low-Level Waste Disposal Site, CERCLA Action," Proceedings of the Ninth Annual DOE Low-Level Waste Management Conference: Session 5, Site Closure and Stabilization, August 1987.

Hobson, N., Deserts as Dumps, "Chapter 9: Disposal of Low-Level Radioactive Waste and Hazardous Chemical Waste at US Ecology's Beatty Nevada Disposal Facility," (Anticipated publication spring 1990).

Illinois Department of Nuclear Safety, Environmental Monitoring Report: "Sheffield Low-Level Radioactive Waste Disposal Site, 1967-1988," March 1989.

Lyverse, M.A., "Tritium Migration at the Low-Level Radioactive Waste Disposal Site at Maxey Flats near Morehead, Kentucky," Proceedings of the Seventh Annual Participants' Information Meeting DOE Low-Level Waste Management Program, February 1986.

New York State Energy Research and Development Authority, Executive Summary of the Site Stabilization Study for the LLRW Disposal Area at West Valley, New York, December 1986.

Office of Technology Assessment, Partnerships Under Pressure: Managing Commercial Low-Level Radioactive Waste, November 1989.

Report to the Chairman, Subcommittee on Energy and Power, Committee on Interstate and Foreign Commerce, House of Representatives of the U.S., Comptroller General, EMD-80-69, "Status of Efforts to Clein Up the Shut Down Western New York Nuclear Service Center," June 6, 1980.

South Carolina, Chapter 48 of the Code of Laws of South Carolina, 1976.

South Carolina Department of Health and Environmental Control Regulation No. 61-83, "Transportation of Radioactive Waste into or within South Carolina," May 22, 1981.

South Carolina Department of Health and Environmental Control, Low-Level Radioactive Waste Disposal in South Carolina, 198x.

State of Illinois v. Teledyne, Inc., and US Ecology, Inc., March 25, 1978.

State of Nevada License No. 13-11-0043-02, June 29, 1977.

State of South Carolina, Radioactive Materials License, License No. 097 (amended), Licensee Chem-Nuclear Systems, Inc.

State of Washington, Radioactive Materials License, License No. WN-1019-2 (amended), Licensee US Ecology, Inc.

State of Washington Executive Order E0 79-09, Relating to the Transport of Commercial Low-Level Radioactive Waste, November 19, 1979. 
U.S. Department of Energy, 1988 Annual Report on Low-Level Radioactive Waste Management Progress, October 1989.

U.S. Department of Energy, Western New York Nuclear Service Center Study, Companion and Summary Reports, November 1978.

U.S. Department of Energy, Spent Fuel and Radioactive Waste Inventories, Projections, and Characteristics, December 1985.

US Ecology, Inc., Comprehensive Facility Utilization Plan; US Ecology LLRW Facility, Richland, WA, November 1986.

US Ecology, Inc., Site Stabilization and Closure Plan for Low-Level Radioactive Waste Management Facility US Ecology, Inc. Beatty, Nevada, December 1988.

U.S. Environmental Protection Agency, Storage of Low-Level Radioactive Wastes in the Ground - Appendix on the Maxey Flats, Kentucky, Radioactive Waste Storage Site - Current Knowledge and Data Needs for a Quantitative Hydrogeologic Evaluation, 1974.

U.S. Geological Survey, Groundwater Hydrology and Subsurface Migration of Radionuclides at a Commercial Radioactive-Waste Burial Site, West Valley, Cattaraugus County, New York, 1986.

U.S. Nuclear Regulatory Commission, Review of the Federal/State Program for Regulation of Commercial Low-Level Radioactive Waste Burial Grounds, NRC Task Force Report, March 1977.

U.S. Nuclear Regulatory Commission, Low-Level Radioactive Waste Burial Criteria, 1E Information Notice No. 80-24, May 1980.

U.S. Nuclear Regulatory Commission, Final Environmental Impact Statement on 10 CFR Part 61, "Licensing Requirements for Land Disposal of Radioactive Waste," November 1982.

U.S. Nuclear Regulatory Comrnission, Draft Environmental Impact Statement on 10 CFR Part 61, "Licensing Requirements for Land Disposal of Radioactive Waste," September 1981 .

U.S. Nuclear Regulatory Commission, Background Information for the Development of a Low-Level Waste Performance Assessment Methodology Identification of Potential Pathways, December 1989.

Waste Management Group, Inc., Directions in Low-Level Radioactive Waste Management "Low-Level Radioactive Waste Disposal: Commercial Facilities No Longer Operating," October 1982.

Waste Management Group, Inc., Directions in Low-Level Radioactive Waste Management "Low-Level Radioactive Waste Disposal: Currently Operating Commercial Facilities," September 1983. 
APPENDIX A

RADIATION BASICS 
APPENDIX A

RADIATION BASICS

Everything in the world is made of atoms. In most of these atoms the number of protons and neutrons in the nucleus are in equilibrium and the atoms are therefore stable or nonradioactive. However, a few kinds of atoms found in nature are unstable or radioactive, for example, uranium, radium, and thorium. The invention of high-energy accelerators and nuclear reactors has allowed the creation of other radioactive atoms, which are unstable counterparts to naturally stable elements. The unstable atoms emit particles (protons, neutrons, or electrons) and/or energy until they reach a stabie, nonradioactive state. These emissions from the unstable atom constitute radiation.

\section{Types of Radiation}

The kind of radiation emitted, its amount of energy, and the period of time it takes to again become stable differs for each radioactive atom. The three basic types of radiation are: alpha, beta, and gamma radiation. A radioactive substance may emit one of these kinds of radiation or a combination of the three.

Alpha radiation consists of particles, each of which is a cluster of two protons and two neutrons ejected from an unstable nucleus. Alpha radiation loses its energy very quickly when passing through matter (Figure A-1). As a result, most alpha radiation travels only a few inches in air and can be stopped by a sheet of paper or the outer layer of human skin. Alpha radiation can be very damaging to body organs, especially lungs, if the alpha source atoms are inhaled as fine particles.

Beta radiation also consists of particles. In this case electrons, about $1 / 7400$ the size of alpha particles, are emitted. Beta particles travel farther in air than alpha particles (as far as 12 to 15 feet) and can penetrate several layers of human skin. Because beta particles can penetrate the skin, the human body can be damaged by being near a source of beta 


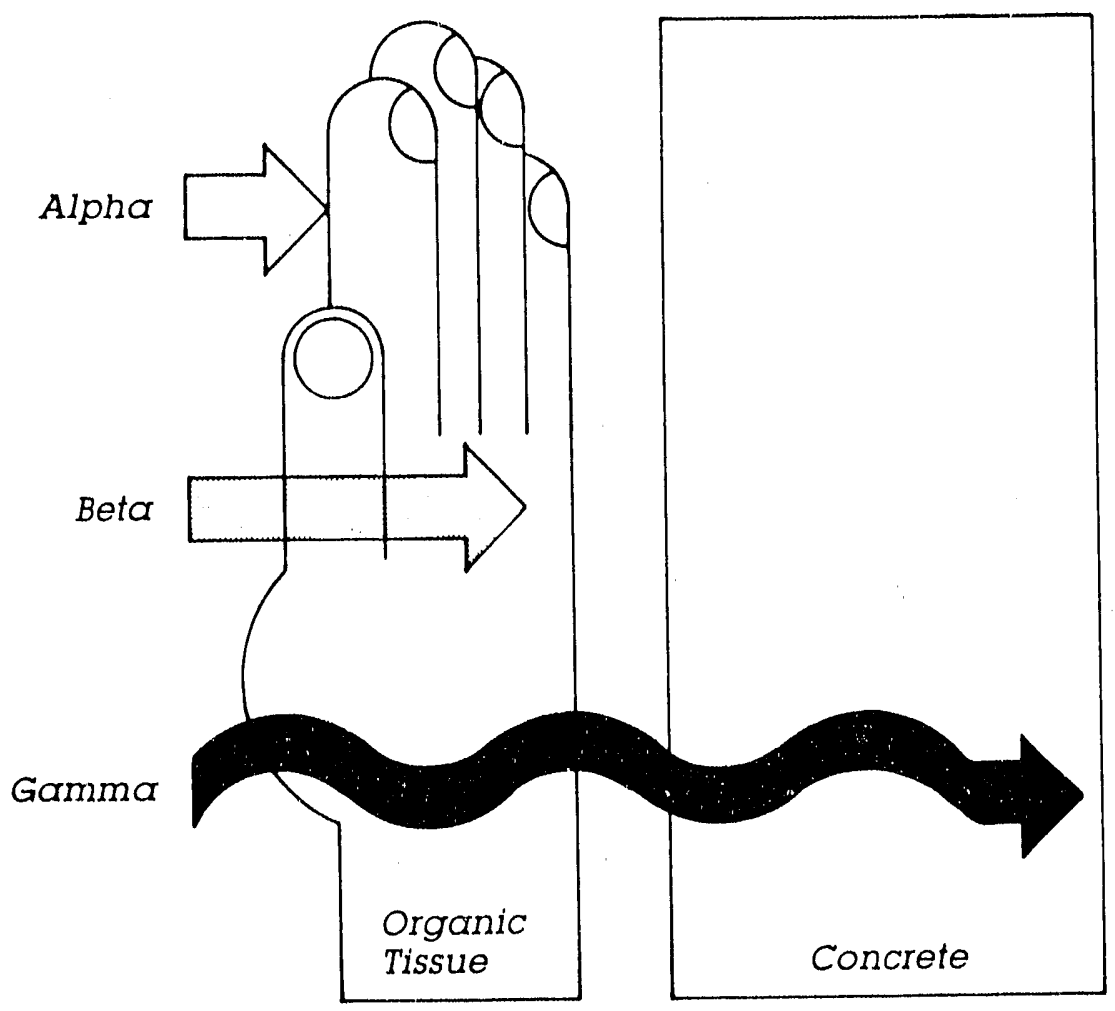

Figure A-1. Radiation penetration. 
radiation for a long period of time or by ingesting a source of beta radiation. Beta radiation can be reduced or stopped by sheets of aluminum, glass, plastic, or wood about an inch thick.

Gamma radiation does not consist of particles, but of waves of energy. It is like light waves or radio waves, but it contains much more energy. Gamma radiation can travel great distances and easily penetrate matter. It can pass completely through the human body, damaging cells enroute, or be absorbed by tissue and bone. Three feet of concrete or two inches of leac are required to stop $90 \%$ of typical gamma radiation.

\section{Radioactive Decay}

Through the process of radioactive decay, al1 radioactive elements eventually reach a stable state and stop emitting radiation. The amount of time these elements take to reach stability varies greatly among the different atoms and is measured in "half-lives." A half-life is the time in which half the atoms of a particular radioactive substance decay to another isotope. A11 radioactive elements have precise and predictable half-lives, ranging from a fraction of a second to more than a billion years (Table A-1).

What this means for low-level radioactive waste disposal is that the risk from a low-level waste disposal facility naturally decreases with time because the amount of radioactivity remaining at the facility decreases exponentially over time (Figure A-2). For example, the West Valley, New York disposal facility had received approximately 106,000 curies of tritium (H-3) before operations ceased in 1975. Since tritium has a half-life of 12.3 years, by 1988 half of the tritium had decayed leaving only 53,000 curies. By 2001, half of the remaining tritium will have decayed, leaving only 26,500 curies. It is through this process of radioactive decay that disposal sites become less and less hazardous and evnntually reach a state when the consequences of intrusion are negligible. 
Table A-1. Half-lives for representative radionuclides in commercially generated low-level radioactive waste.

\begin{tabular}{|c|c|c|}
\hline Radionuclide & Symbol & Half-Life \\
\hline $\begin{array}{l}\text { Americium-241 } \\
\text { Antimony-125 } \\
\text { Barium-137m } \\
\text { Carbon- } 14 \\
\text { Cerium-144 }\end{array}$ & $\begin{array}{l}\text { Am- } 241 \\
\mathrm{Sb}-125 \\
\mathrm{Ba}-137 \mathrm{~m} \\
\mathrm{C}-14 \\
\mathrm{Ce}-144\end{array}$ & $\begin{array}{l}432.2 \text { years } \\
2.77 \text { years } \\
2.55 \text { minutes } \\
5730 \text { years } \\
284.3 \text { days }\end{array}$ \\
\hline $\begin{array}{l}\text { Cesium-134 } \\
\text { Cesium-137 } \\
\text { Chromium- } 51 \\
\text { Cobalt }-58 \\
\text { Cobalt- } 60\end{array}$ & $\begin{array}{l}C s-134 \\
C s-137 \\
C r-51 \\
C 0-58 \\
C 0-60\end{array}$ & $\begin{array}{l}2.06 \text { years } \\
30.17 \text { years } \\
27.7 \text { days } \\
70.8 \text { days } \\
5.27 \text { years }\end{array}$ \\
\hline $\begin{array}{l}\text { Europium-152 } \\
\text { Europium-154 } \\
\text { Europium-155 } \\
\text { Hydrogen-3 } \\
\text { Iron-59 }\end{array}$ & $\begin{array}{l}E u-152 \\
E u-154 \\
E u-155 \\
H-3 \\
F e-59\end{array}$ & $\begin{array}{l}13.6 \text { years } \\
8.8 \text { years } \\
4.96 \text { years } \\
12.3 \text { years } \\
44.63 \text { days }\end{array}$ \\
\hline $\begin{array}{l}\text { Manganese- } 54 \\
\text { Niobium- } 95 \\
\text { Promethium-147 } \\
\text { Praseodymium-144 } \\
\text { Plutonium- } 238\end{array}$ & $\begin{array}{l}\mathrm{Mn}-54 \\
\mathrm{Nb}-95 \\
\mathrm{Pm}-147 \\
\mathrm{Pr}-144 \\
\mathrm{Pu}-238\end{array}$ & $\begin{array}{l}312.7 \text { days } \\
35.06 \text { days } \\
2.62 \text { years } \\
17.28 \text { minutes } \\
87.75 \text { years }\end{array}$ \\
\hline $\begin{array}{l}\text { Plutonium-239 } \\
\text { Radium-226 } \\
\text { Rhodium-106 } \\
\text { Ruthenium-106 } \\
\text { Samarium-151 }\end{array}$ & $\begin{array}{l}\mathrm{Pu}-239 \\
\mathrm{Ra}-226 \\
\mathrm{Rh}-106 \\
\mathrm{Ru}-106 \\
\mathrm{Sm}-151\end{array}$ & $\begin{array}{l}24,130 \text { years } \\
1600 \text { years } \\
299 \text { seconds } \\
368.2 \text { days } \\
90 \text { years }\end{array}$ \\
\hline $\begin{array}{l}\text { Strontium-90 } \\
\text { Technetium-99 } \\
\text { Tellurium-125m } \\
\text { Thorium-232 } \\
\text { Uranium-235 }\end{array}$ & $\begin{array}{l}\text { Sr }-90 \\
\text { Tc-99 } \\
\text { Te-125m } \\
\text { Th- } 232 \\
U-235\end{array}$ & $\begin{array}{l}28.6 \text { years } \\
213,000 \text { years } \\
58 \text { days } \\
14 \text { billion years } \\
7 \text { million years }\end{array}$ \\
\hline $\begin{array}{l}\text { Uranium-238 } \\
\text { Yttrium-90 } \\
\text { Zinc-65 } \\
\text { Zirconium-95 }\end{array}$ & $\begin{array}{l}U-238 \\
Y-90 \\
Z n-65 \\
Z r-95\end{array}$ & $\begin{array}{l}45 \text { million years } \\
61 \text { hours } \\
244 \text { days } \\
64 \text { days }\end{array}$ \\
\hline
\end{tabular}

From U.S. Department of Energy, Integrated Data Base for 1988: Spent Fuel and Radioactive Waste Inventories, Projections, and Characteristics, September 1988. 
NOTE TO TABLE A-1: Low-level radioactive waste typically contains both shortlived and long-lived radionuclides. Concentrations of short-lived radionuclides permitted in the waste are higher than concentrations of longlived radionuclides, because the short-lived nuclides will significantly decay during the 100 years of assumed institutiond control. Low-level waste that exceeds certain concentrations of long-lived radionuclides is the responsibility of the Federal Government and will not be disposed of in commercially operated disposal sites. 


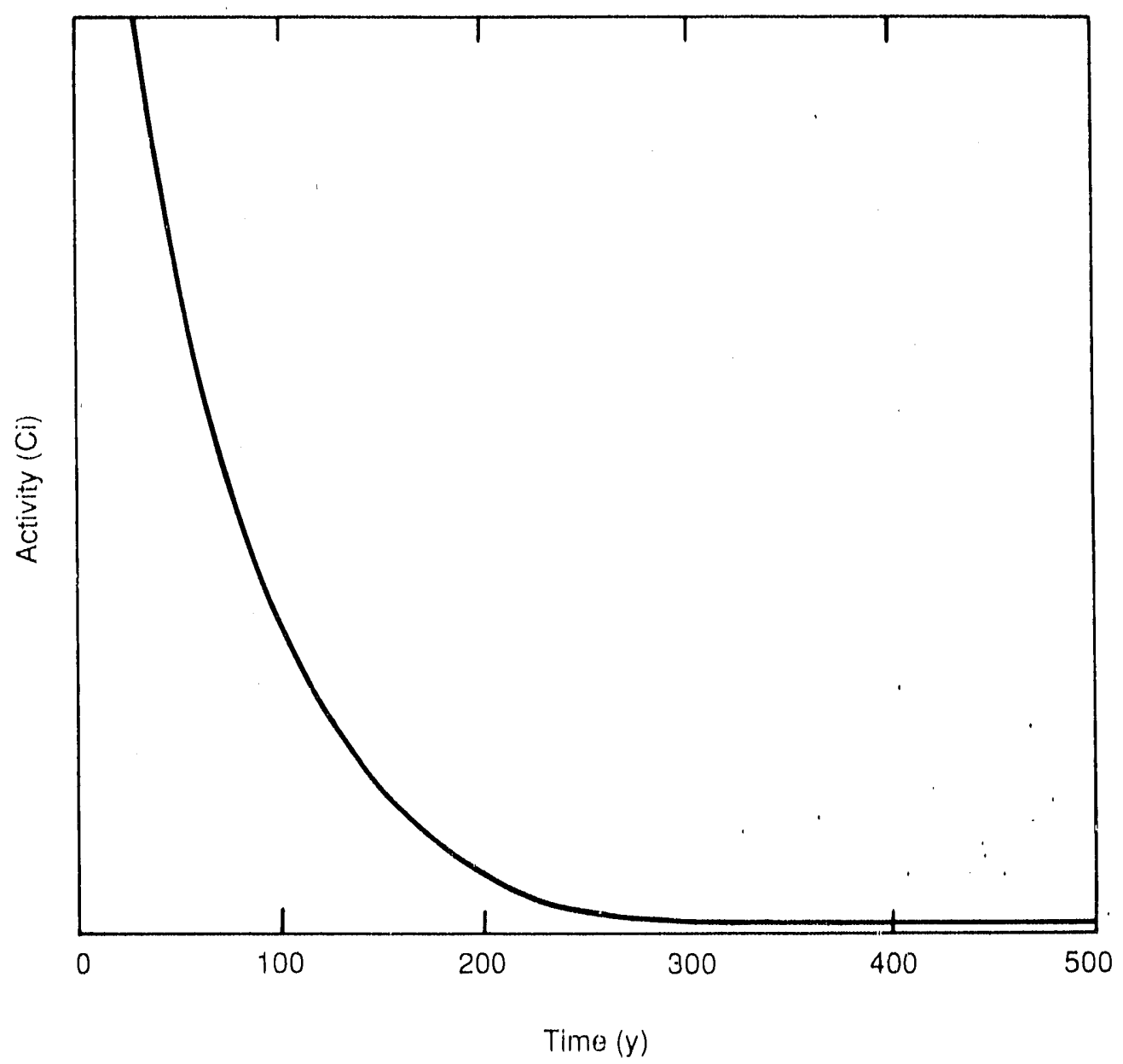

0.8123

Figure A-2. Natural decay curve of radionuclides. 


\section{Radiation Exposure}

Most of us are familiar with the Geiger counter, one type of instrument used to measure radioactivity. Similar instruments can measure amounts and types of radioactivity in the air, soil, water, or on the surface of objects. Each radioactive atom has its own signature, which consists of the types of radiation it emits, the specific energy levels of the radiation, and its precise rate of decay. By measuring these three things, scientists can identify a radioactive atom and know how much of it there is, even if the amount is very small.

Quantities of radiation are measured and expressed in several ways. Most useful for this discussion is the unit called a "rem," because it takes into account both the energy carried by the radiation and the way that energy is absorbed in biological tissue. A rem (roentgen equivalent man) is a unit used in radiation protection to measure the amount of damage to human tissue from a dose of radiation. Because whole rem exposures are rare, the unit most often used is the "millirem," or 1/1000 of a rem. One hundred millirem equals $1 / 10$ rem; 500 millirem equals $1 / 2$ rem; and so on.

The Nuclear Regulatory Commission (NRC) and the Environmental Protection Agency (EPA) set and maintain the standards for radiation exposures that members of the public are allowed to receive in addition to background radiation. According to the current standards, individual members of the public may receive up to 500 millirem of radiation annually, excluding medical and dental x-rays, above the amount received as an annual background dose. The standards recommend that we receive an annual average dose of no more than 170 millirems. In other words, an individual should not receive the maximum dose year after year. Within that maximum limit, an individual can receive no more than 25 millirem per year from the disposal of radioactive waste. 


\section{APPENDIX B}

RADIONUCLIDE MIGRATION AND PERFORMANCE ASSESSMENT

1 


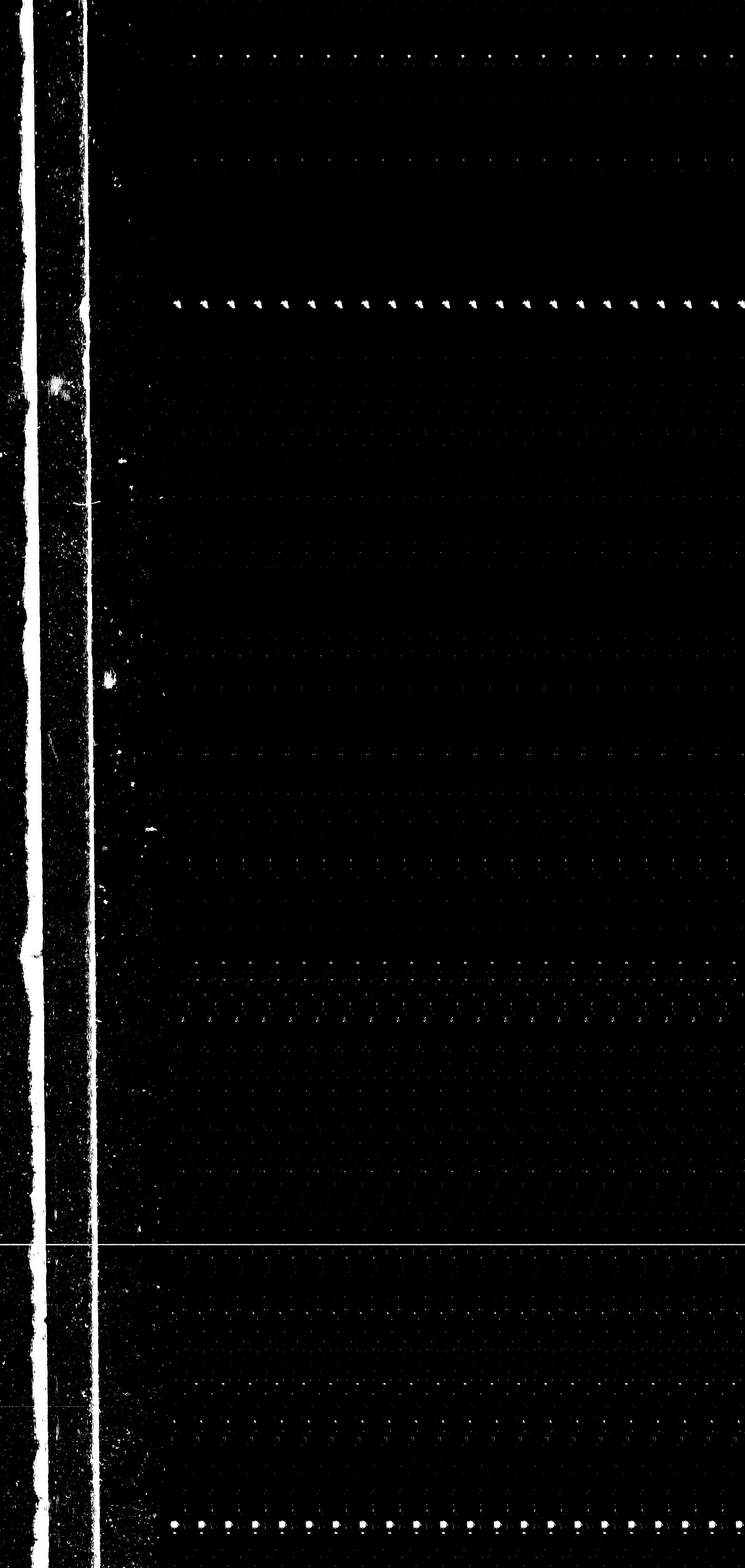


APPENDIX B

RADIONUCLIDE MIGRATION AND PERFORMANCE ASSESSMENT

\section{Radionuclide Migration}

Radionuclides that are not adequately contained can be released from radioactive aterial or waste a d transported through both the geosphere (air, soil, sur, water, and groundwater) and the biosphere (plants and animals). Complex interactions may occur as radionuclides migrate through various components in the environment. Doses to humans may occur as a result of direct exposure to natural or manufactured materials that emit radioactivity. These doses may be either external (gamma radiation and surface contact) or internal (inhalation and ingestion) or a combination of the two.

Radionuclide "pathways" which result in human exposure involve a release of radionuclides, coupled with migration through the environment. A simplified diagram of the migration and exposure pathways is presented in Figure B-1. Boxes in the figure represent media that may become contaminated with radionuclides and transport them from one location to another. Airrows indicate mechanisms by which radionuclides may be transferred from one medium to another. "Direct radiation" in this figure implies exposure to direct gamma radiation resulting from immersion in, or proximity to, contaminated materials. Numerous pathways may be traced in this figure. In all cases, with the exception of direct radiation exposure from the waste, the pathways are composed of an exposure mechanism by which radionuclides released from the waste migrate through one or more media within the environment, and ultimately reach humans.

Direct contact, ai. contact, and water contact are the three primi.y exposure mechanisms for low-level waste at shallow-land disposal facilities. Direct contact mobilization is caused primarily by human ane nimal activities that disturb the waste. Wastes brought to the surface by rooting plants are also the result of direct cor act. Air contact mobilization occurs when waste is exposed to the atmosphere anúd winu curreñs mótilize waste partictes. Water-contact mobilization results from processes such as dissolution, 


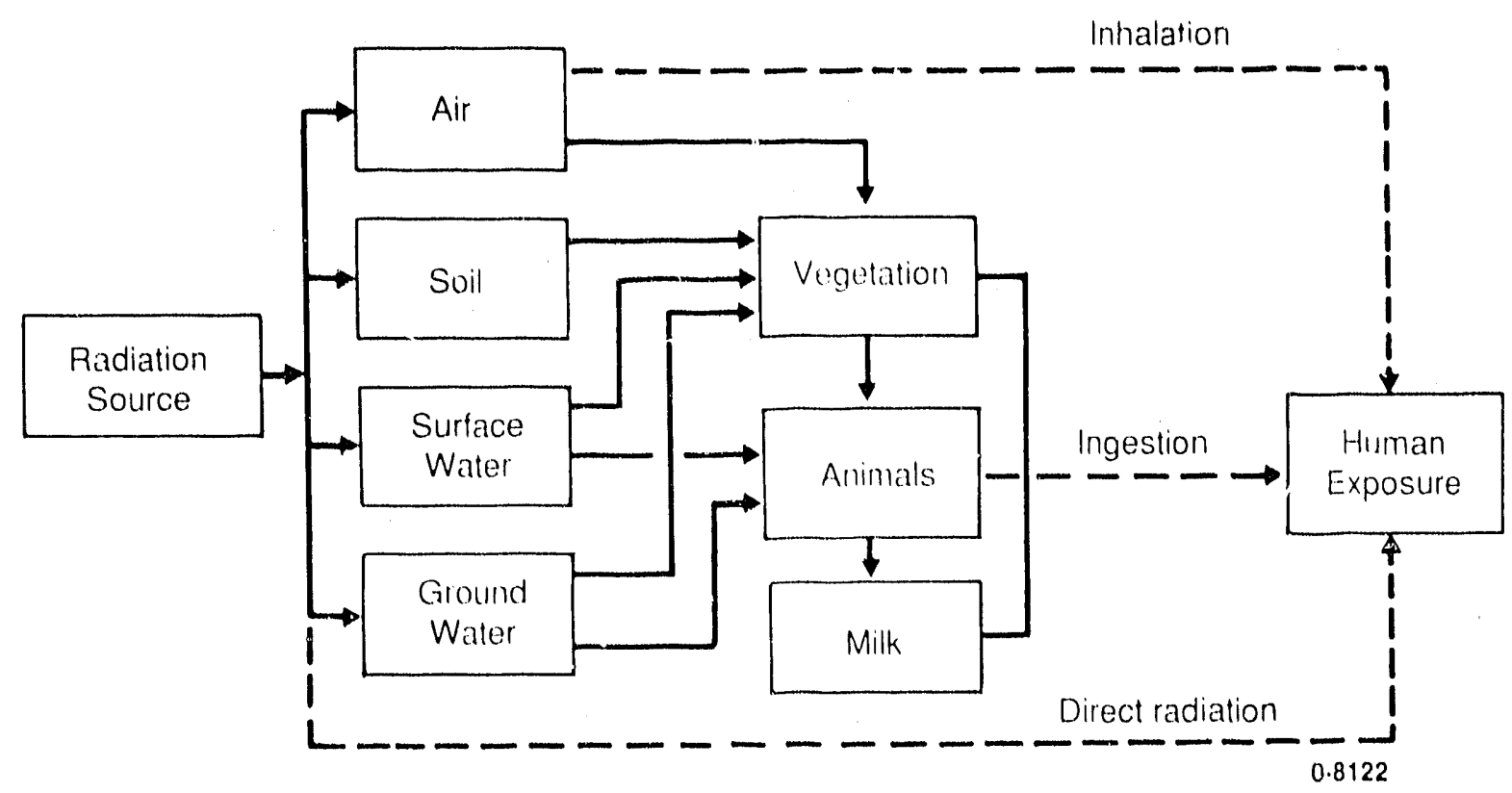

Figure B-1. Potential radionuclide migrution and exposure pathways. 
diffusion, desorption, and ion exchange. Once the waste has been mobilized, the following four primary media exist for transporting radionuclides: air, surface water, groundwater, and food chain.

Facility performance objectives have been established by the Nuciear Regulatory Commission (NRC) for the protection of public health, safety, and environmental resources. These performance objectives, which are consistent with other Federal, State, and local requirements, require that annual dose equivalents not exceed 25 millirems to the whole body, 75 millirems to the thyroid, and 25 millirems to any other organ of any member of the public. The disposal facility must be sited, designed, operated, and closed to achieve long-term stability and to ensure protection from inadvertent intrusion for these objectives to be achieved.

\section{Performance Assessment}

Performance assessment is a systematic analysis of a low-level waste disposal facility and its surrounding environment, with the intent of demonstrating compliance with established performance objectives. Present conditions and future scenarios must be considered for that period of time in which significant impacts remain a possibility.

The goal of a performance assessment is to calculate potential radioactivity at various human access locations. A description of the physical properties of the low-level waste disposal facility and its surrounding environment, as well as the kinetic behavior of the environment must be defined. This involves determining potential pathways and specific locations for human exposure to radioactive concentration, development of appropriate scenarios, and the assurance and control of the quality of all data.

A team of technical professionals is required in order to conduct a performance assessment. The qualified team might consist of scientists with backgrounds in hydrology, geochemistry, ecology, geology, and metcorology. 
Professionals with training in waste management, environmental assessment, mathematics, physics, modeling, and computer programming may also be included.

The performance assessment process includes data collection, model development, and performance assessment calculations. Data requirements include: (a) waste characteristics such as activity, volume, and physical form; (b) physical site characteristics such as size and type of disposal facility; (c) disposal procedures; (d) biotic considerations such as the composition and abundance of plant and animal communities; and

(e) environmental factors including meteorological, geochemical, hydrological, and geologic characteristics.

Once sufficient data have been collected, conceptual models of the disposal system are developed. These models include: (a) a facility model to describe the release of radionuclides within the facility; (b) a transport model to tescribe the movement of these radionuclides; (c) a demographic model to show the spatial distribution of the human population around the disposal facility; and (d) an exposure model to describe which, and how, receptors become exposed. The conceptual models are eventually translated into mathematical equations and computer programs.

Once appropriate mathematical equations and computer codes have been developed and verified, performance assessment calculations can be performed. Information about waste volume, activity, and radionuclides is input into the computer program. The program creates a simulation of the disposal facility and predicts the radioactivity at various human access locations at various periods of $t$ ine. The results of the simulation are compared with the performance objectives to determine if the facility's predicted performance meets the criterion. If the predicted dose is less than the dose limit, it can be concluded that the facility is in compliance with the objective. If the projected dose exceeds the dose limit, and there is reasonable confidence in the model, action must be taken to mitigate the impact of the proposed facility on the environment. 
As part of the licensing process, performance assessments will be reviewed by the NRC or the appropriate Agreement State agency to determine the proposed facility's adequacy in demonstrating regulatory compliance. Although not necessarily required, an independent performance assessment may be conducted by the NRC to verify an applicant's calculations. 
APPENDIX C

DISPOSAL TECHNOLOGIES 


\section{APPENDIX C \\ DISPOSAL TECHNOLOGIES}

Federal regulations for low-level radioactive waste disposal do not require that a particular disposal technology be used or that one disposal technology be used in preference to another. Instead, the regulations set forth site performance requirements that must be met, regardless of the disposal technology chosen for use at the site. These requirements are designed to protect the public from releases of radioactivity, protect individuals from inadvertent intrusion into the waste, protect workers during operation, and ensure stability of the site after closure.

Among the many disposal technology options available to States and compact regions developing new low-level waste disposal sites, six concepts are most frequently considered. Following are brief descriptions of these concepts.

The shallow-land disposal concept consists of placing waste containers in an engineered trench (about 30 feet below grade) that is designed for the specific needs of each facility (Figure $C-1$ ). Voids between containers are backfilled with sand or other suitable material. Generally, each trench is a long, narrow, evacuation with an engineered floor, cover system, drainage collection system, and monitoring system. The trench is closed with an earthen cover to minimize water infiltration and reduce surface radiation exposure.

The intermediate depth disposal concept closely resembles shallow-land disposal. The primary differences are: (a) the excavated trench is deeper, and (b) the earthen cover is significantly thicker (approximately thirtytwo feet).

The belowground vault disposal concept for low-level radioactive waste consists of placing the waste in an engineered concrete vault located below the natural grade of the disposal site (Figure $\mathrm{C}-2$ ). The concrete structure cunsisis of reinforced floors, vialls, and a roof. The vault also contains a 


$$
\text { 舟 }
$$




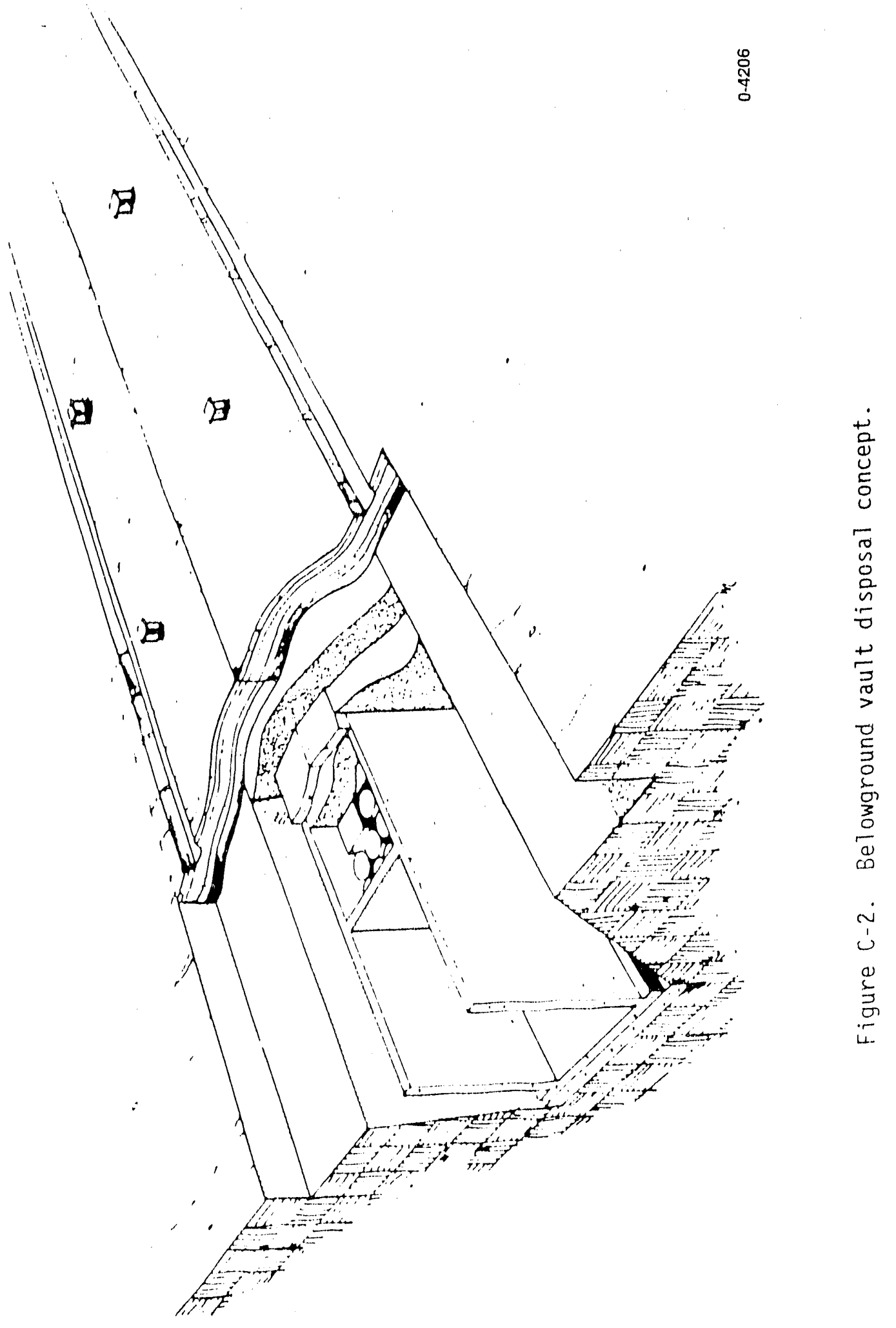


drainage collection system and a monitoring system. Waste containers are stacked in the vault; voids between waste containers are backfilled with sand and compacted. The concrete roof is poured in place, and th 2 vault is capped with an earthen cover. The earthen cover minimizes water infiltration and reduces surface radiation exposure.

Belowground vault disposal differs from shallow.land disposal in that concrete structures are used as engineered enhancements. These enhancements provide additional structural stability to the disposal unit and reduce surface radiation levels.

The aboveground vault disposal concept differs from other disposal concepts in that it does not use an earthen cover (Figure $\mathrm{C}-3$ ). The waste is placed in an engineered concrete vault consisting of reinforced floors, walls, and a roof. The vault also contains drainage collection and monitoring systems. The waste containers are stacked in the vault, voids betwen containers are backfilled with sand, and a concrete roof is poured in place over each backfilled cell to close the disposal unit. Without an earthen cover, the aboveground vault concept relies on the ability of the concrete structure to isolate the waste from the surrounding environment.

The modular concrete canister disposal concept can be used in conjunction with other disposal technologies. The modular concrete canister disposal concept uses specially constructed concrete canisters to provide additional structural stability. Waste is placed in reinforced cuncrete canisters, each sized to hold a particular number of waste containers. Void spaces in each canister are filled with grout. The canisters are then placed and covered according to the other disposal technology being utilized.

The earth-mounded concrete bunker disposal concept includes features of scme of the other concepts. The waste canisters are stacked in a bunker consisting of four reinforced concrete walls constructed above the natural grade of the site. Voids between the canisters are backfilled with sand, and the entire structure is closed with a mounded earthen cover. This concept a!so includes drainage collection and monitoring systems. 


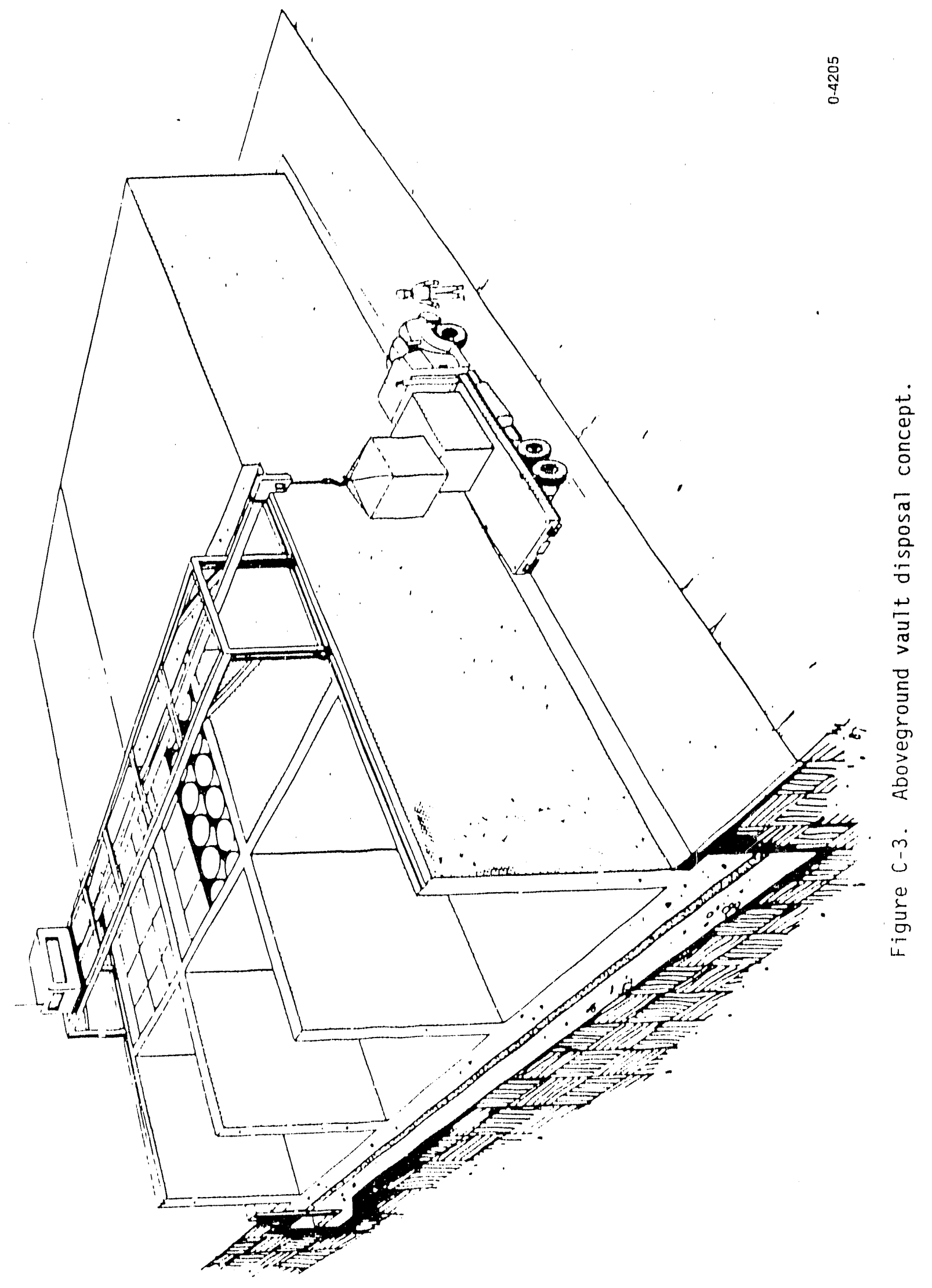



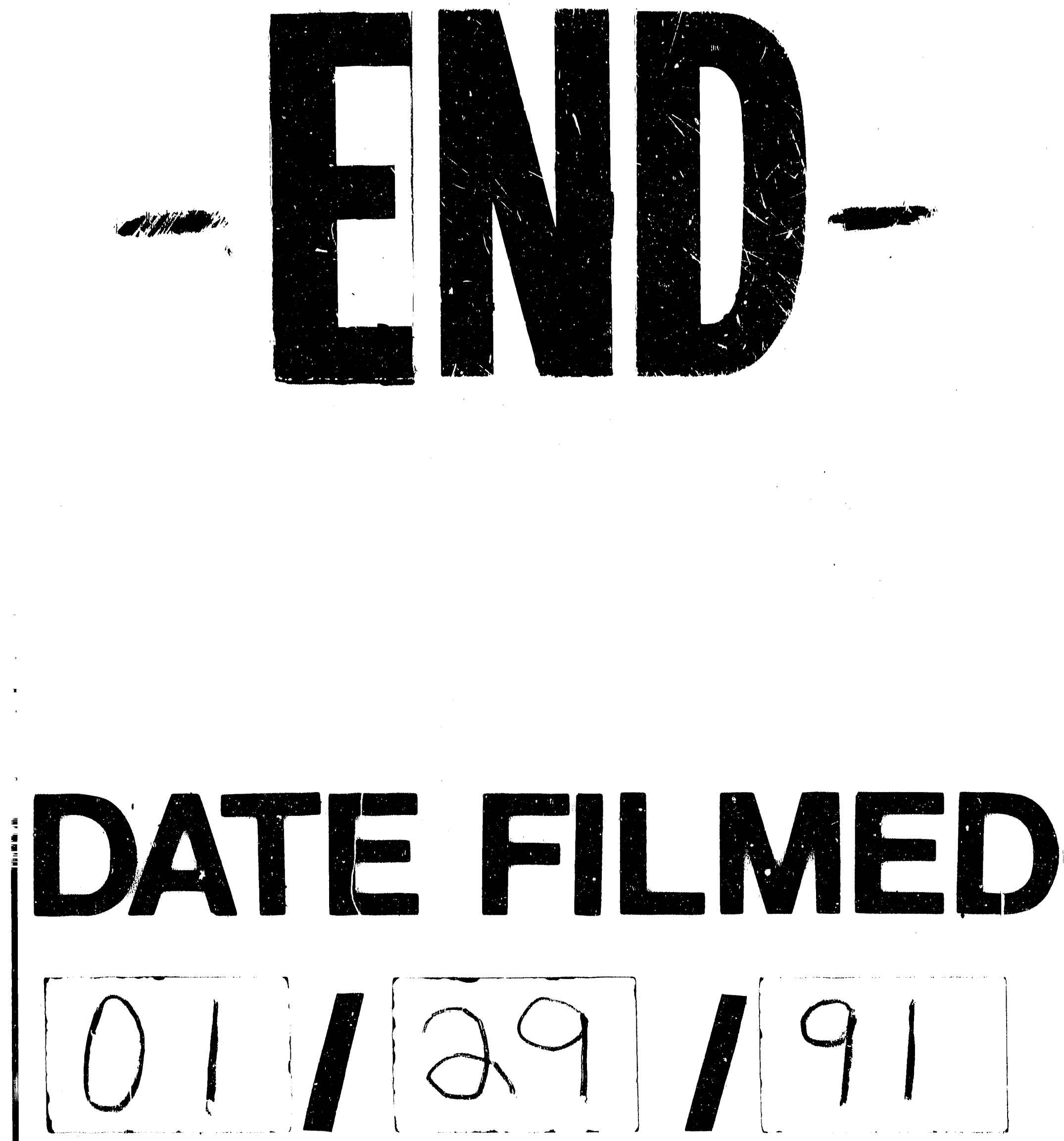
1 